\title{
Distribution and sources of bioaccumulative air pollutants at Mezquital Valley, Mexico, as reflected by the atmospheric plant Tillandsia recurvata $\mathbf{L}$.
}

\author{
A. Zambrano García ${ }^{1}$, C. Medina Coyotzin ${ }^{1}$, A. Rojas Amaro ${ }^{1}$, D. López Veneroni ${ }^{1}$, L. Chang Martínez ${ }^{2}$, and \\ G. Sosa Iglesias ${ }^{1}$ \\ ${ }^{1}$ Dirección Ejecutiva de Investigación y Posgrado, Instituto Mexicano del Petróleo, México D.F., Mexico \\ ${ }^{2}$ Universidad Michoacana de San Nicolás de los Hidalgo, Morelia, Mexico
}

Received: 21 January 2009 - Published in Atmos. Chem. Phys. Discuss.: 4 March 2009

Revised: 18 June 2009 - Accepted: 5 July 2009 - Published: 8 September 2009

\begin{abstract}
Mezquital Valley (MV), a Mexican wastewaterbased agricultural and industrial region, is a "hot spot" of regulated air pollutants emissions, but the concurrent unregulated ones, like hazardous metals and polycyclic aromatic hydrocarbons (PAH), remain undocumented. A biomonitoring survey with the epiphytic Tillandsia recurvata was conducted there to detect spatial patterns and potential sources of 20 airborne elements and $15 \mathrm{PAH}$. The natural $\delta^{13} \mathrm{C}$ and $\delta^{15} \mathrm{~N}$ ratios of this plant helped in source identification. The regional mean concentration of most elements was two $(\mathrm{Cr})$ to over 40 times $(\mathrm{Ni}, \mathrm{Pb}, \mathrm{V})$ higher than reported for Tillandsia in other countries. Eleven elements, pyrene and chrysene had $18-214 \%$ higher mean concentration at the industrial south than at the agricultural north of MV. The total quantified PAH (mean, 572 $\mathrm{ng} \mathrm{g}^{-1}$; range, 143-2568) were composed by medium (65\%, phenanthrene to chrysene), low (28\%, naphthalene to fluorene) and high molecular weight compounds (7\%, Benzo $(b)$ fluoranthene to indeno(1,2,3-cd)pyrene). The $\delta^{13} \mathrm{C}$ (mean, $-14.6 \%$; range, $-15.7 \%$ o to $-13.7 \%$ ) was consistently lower than $-15 \%$ near the major petroleum combustion sources. The $\delta^{15} \mathrm{~N}$ (mean, $-3.0 \%$; range, $-9.9 \%$ o to $3.3 \%$ ) varied from positive at agriculture/industrial areas to negative at rural sites. Factor analysis provided a five-factor solution for $74 \%$ of the data variance: 1) crustal rocks, $39.5 \%$ (Al, Ba, $\mathrm{Cu}, \mathrm{Fe}, \mathrm{Sr}, \mathrm{Ti}) ; 2$ ) soils, $11.3 \%$, contrasting contributions from natural $(\mathrm{Mg}, \mathrm{Mn}, \mathrm{Zn})$ and saline agriculture soils (Na); 3) cement production and fossil fuel combustion, 9.8\% (Ca, Ni, V, chrysene, pyrene); 4) probable agricultural biomass burning, $8.1 \%$ (K and benzo $(g, h, i)$ perylene), and
\end{abstract}

Correspondence to:

A. Zambrano García

(azambran@imp.mx)
5) agriculture with wastewater, $5.2 \%\left(\delta^{15} \mathrm{~N}\right.$ and $\left.\mathrm{P}\right)$. These results indicated high deposition of bioaccumulative air pollutants at MV, especially at the industrial area. Since T. recurvata reflected the regional differences in exposition, it is recommended as a biomonitor for comparisons within and among countries where it is distributed: southern USA to Argentina.

\section{Introduction}

Monitoring airborne metals, polycyclic aromatic hydrocarbons (PAH) and other bioaccumulative compounds with living organisms (biomonitoring) is a technique in use and refinement since at least the 1960's. It is a multipurpose environmental tool for exploring pollutant occurrence and dispersion trends at different geographical/time scales, to identify emission sources, estimate atmospheric deposition and relate biological/ecological changes to air pollution (Aboal et al., 2006; Conti and Cecchetti, 2001; Pirintsos and Lopi, 2008; Segala et al., 2008; Wolterbeek, 2002). Since bioaccumulative air pollutants usually travel in particles, biomonitoring is done preferentially with organisms that rely on the atmosphere as primary source of moisture and nutrients, such as lichens, mosses and some vascular plants. This dependence is indicated by positive correlations between the concentration of pollutants in the biomonitor tissues and the amount of atmospheric deposition (Sloff, 1995; St. Clair et al., 2002; Wolterbeek, 2002).

We report results from a biomonitoring survey of airborne metals and PAH at Mezquital Valley (MV) conducted in the context of the MILAGRO 2006 field campaign in Mexico. This region is environmentally better known by severe

Published by Copernicus Publications on behalf of the European Geosciences Union. 
soil and water pollution problems caused by over 100 years of agricultural irrigation with untreated sewage water from Mexico City (Cifuentes et al., 1994; Downs et al., 1999; Friedel et al., 2000; Siebe, 1994; Vázquez-Alarcón et al., 2001). Mezquital Valley is also a major Mexican "hot spot" in emissions of particulate matter, $\mathrm{SO}_{2}$ and other regulated pollutants by the Tula-Tepeji-Vito industrial corridor located there (SEMARNAT-INE, 2006). Nevertheless, there is very little information on the expected concurrence of unregulated air toxics at MV, such as hazardous metals, PAH and other persistent organic pollutants.

This survey explored MV for spatial deposition trends and potential sources of 20 trace and major elements and 15 hazardous PAH using the "ball moss" (Tillandsia recurvata L.) as a natural receptor. This epiphytic Bromeliaceae is very common at the study region, where it mainly grows on mesquite trees (Prosopis laevigata (Willd) M. C. Johnst.). Adult individuals are spherical, ca. $10-12 \mathrm{~cm}$ in diameter, easy to recognize in the field and collect by hand. They have a reduced stem and non-functional roots. Most of their biomass is formed by linear leaves profusely covered with absorptive trichomes. This latter morphological feature increases the ability of this plant to capture moisture and particles directly from the surrounding air, which justifies naming it as an "air" or "atmospheric" plant (Schmitt et al., 1989). Tillandsia recurvata has some physiological resistance to high levels of $\mathrm{O}_{3}$ and $\mathrm{SO}_{2}$ (Benzig et al., 1992), which may partially explain why is it so abundant at the polluted MV. This and other atmospheric Tillandsia species have been used as in situ air pollution biomonitors in some southern US states and Latin-American countries, where this genus is exclusively distributed (e.g., De Sousa et al., 2007; Husk et al., 2004; Pignata et al., 2002; Pyatt et al., 1999; Schrimpff, 1984; Smodiš et al., 2004; Wannaz et al., 2006a, b). Successful transplanting of Tillandsia from rural into urban areas for similar purposes has been reported by Brighina et al. (2002), Figuereido et al. (2007), and Malm et al. (1998).

The natural $\delta^{13} \mathrm{C}$ and $\delta^{15} \mathrm{~N}$ stable isotope ratios of $T$. recurvata were determined as additional information to identify regional sources of air pollution. These ratios express the ${ }^{13} \mathrm{C}$ to ${ }^{12} \mathrm{C}$ and ${ }^{15} \mathrm{~N}$ to ${ }^{14} \mathrm{~N}$ proportions in the samples relative to their proportions in standard materials. They are sensitive to spatial and time variations in the isotopic composition of the $\mathrm{C}$ and $\mathrm{N}$ sources used by plants (Bukata and Kyser, 2007; Liu et al., 2008; Norra et al., 2005; Skinner et al., 2006; Solga et al., 2006). Since most constitutive plant carbon derives from ${ }^{12} \mathrm{CO}_{2}$ fixed directly from the atmosphere by photosynthesis, plant $\delta^{13} \mathrm{C}$ ratios are particularly useful in detecting air pollution by the ${ }^{12} \mathrm{C}$-rich emissions from fossil fuel combustion. These emissions have significantly lower ${ }^{13} \mathrm{CO}_{2}:{ }^{12} \mathrm{CO}_{2}$ ratios than unpolluted air, as indicated by $\delta^{13} \mathrm{C}$ values around $-25 \%,-30 \%,-40 \%$ o and $-8 \%$ or coal, petroleum, natural gas and clean air, respectively (Pichlmayer et al., 1998). The mixing of fossil fuel emissions with clean air is thus related to the commonly low air $\delta^{13} \mathrm{C}$ values at urban/industrial areas compared to rural/remote locations (e.g., $-12 \%$ ov. $-8 \%$, respectively, Boutton, 1991). Because of the increase in the air concentrations of ${ }^{12} \mathrm{CO}_{2}$ caused by fossil fuel emissions and the preferential photosynthetic fixation of this form of carbon dioxide over ${ }^{13} \mathrm{CO}_{2}$, plants exposed to such pollution develop lower $\delta^{13} \mathrm{C}$ values than those growing under clean air. In contrast, the plant $\delta^{15} \mathrm{~N}$ changes related to air pollution sources cannot be interpreted straightforward because of the variety of $\mathrm{N}$ compounds involved, their emission and deposition forms, and the complex isotopic fractionation processes occurring within and between the sources and the plant receptors. The natural $\delta^{15} \mathrm{~N}$ values of land plants range roughly from $-7 \%$ to $+9 \%$ (Kelly et al., 2005). They can change because of the isotopic composition of the $\mathrm{N}$ sources and the ability of each plant species to discriminate against ${ }^{15} \mathrm{~N}$. In general, for plants obtaining nutrients exclusively from atmospheric sources, this ratio decreases if the deposited $\mathrm{N}$ compounds are dominated by $\delta^{15} \mathrm{~N}$ values lower than theirs. Such compounds are usually reduced $\mathrm{N}$ species abundant at, but not restricted to, agriculture/farming areas: e.g., ammonia $\left(\mathrm{NH}_{3}, \delta{ }^{15} \mathrm{~N}\right.$ : $-10 \%$ o to $-40 \%$, several sources). Contrarily, this ratio increases in plants predominantly exposed to compounds with $\delta^{15} \mathrm{~N}$ values higher than theirs, mainly oxidized $\mathrm{N}$ species $\left(\mathrm{NO}_{\mathrm{x}}\right)$, which are more common to urban/industrial areas because of the heavier use of fossil fuels (Jung et al., 1997; Skinner et al., 2006; Solga et al., 2005). Since agriculture and industry coexist at our study area, we expected the T. recurvata $\delta^{13} \mathrm{C}$ and $\delta^{15} \mathrm{~N}$ to reflect these land uses.

A data matrix with $50 \mathrm{MV}$ sites and 38 chemical variables was reduced by standard univariate statistical techniques. Exploratory factor analysis (FA) of selected variables and mapping allowed us to detect the major regional emission sources. As far as we know, this is the first report on the bioaccumulative air pollution of MV using biomonitoring techniques.

\section{Materials and methods}

\subsection{Study area}

Mezquital Valley is located in Hidalgo State, Mexico, ca. $60 \mathrm{~km}$ NW of Mexico City (Fig. 1). It is a semiarid region (ca. $2429 \mathrm{~km}^{2}$ ) with about 500000 inhabitants distributed in medium-size towns (e.g., Tula and Tepeji del Río) and many small villages. The mean annual temperature and precipitation range from $16.5^{\circ} \mathrm{C}$ and $432 \mathrm{~mm}$ at the north portion of the valley, which is mainly dedicated to agriculture, to $17.2^{\circ} \mathrm{C}$ and $647 \mathrm{~mm}$ at the industrialized south. The mean elevation at the agriculture flatlands is $2000 \mathrm{~m}$ a.m.s.l., and up to $2400 \mathrm{~m}$ at the surrounding mountains. The original valley's vegetation was a xerophytic shrubland with "mesquite" tree as dominant element. This vegetation disappeared at the 
agricultural areas and is now restricted to the foothills and highlands. Over 90000 ha of MV are currently dedicated to agriculture with raw sewage water from Mexico City. This is the major cause of chemical and biological contamination of the regional soils (Siebe and Cifuentes, 1995). The TepejiTula-Atitalaquia industrial corridor has about 140 industries, including a petroleum refinery (325000 barrels day ${ }^{-1}$ ); a $1500 \mathrm{MW}$ electricity power plant fueled with residual fuel oil and, secondarily, with natural gas, and over 20 cement plants. That power plant is the largest emitter of air toxics among similar Mexican facilities (CEPAL-SEMARNAT, 2004). The regional cement production relies on raw limestone material obtained nearby by dusty quarries. Cement is processed using residual fuel oil, petroleum coke and other materials, like used tires and industrial wastes. Other MV industries include non-ferrous metal manufacturing, textile, chemical, processed food, and disposal, recycling or incineration of waste materials. Cabrera et al. (2003) estimated the MV emissions of total suspended particles (TSP) from industrial and mobile sources in 21538 ton year $^{-1}$. This is a rather large amount representing ca. $80 \%$ of the same emissions at the much larger and higher populated Mexico City (27 308 ton $\mathrm{year}^{-1}$, SMA, 2006). The contribution from natural and agricultural sources to the MV air pollution is still unknown. Two major regional natural/crustal sources of particulate material are the Cretaceous limestone (El Doctor Formation) that covers about $60 \%$ of MV, mainly exposed at the E-SE sector (Silva-Mora, 1997), and Lower Tertiary igneous rocks, roughly located at the valley's west half.

\subsection{Sampling and sample preparation}

Tillandsia recurvata was sampled at 50 sites throughout MV in the late spring and early summer, 2006 (Fig. 1). Most sites were at mountain foothills where mesquite trees, from which the biomonitor was obtained, are more common. In a few sites lacking this tree, sampling was done on alternative trees and cacti. The mean elevation of the sampling sites was $2200 \mathrm{~m}$ (min, $1879 \mathrm{~m}$; max, $2435 \mathrm{~m}$ ). Three composite samples per site were collected from tree branches at $\geq 1 \mathrm{~m}$ from the ground, each composed by six to eight "ball moss" individuals from different trees. Cross contamination between samples was avoided by wearing new dust-free latex gloves per sample. Samples were taken to the laboratory in air-dried condition in brown paper bags, and stored at ambient temperature until processing (late September-October 2006). They were manually cleaned prior to chemical analyses by removing dead plant parts as well as insects, feathers and spider webs, among other materials extraneous to the samples, but were not subjected to further cleaning procedures, as recommended for air pollution biomonitoring with plants (Rossini Oliva and Raitio, 2003). The samples were then subdivided into three portions for metal, $\mathrm{PAH}$ and isotopic analyses, and stored in polyethylene bags at $-40^{\circ} \mathrm{C}$ until analyses. Since T. recurvata is perennial, potential age-related variability in

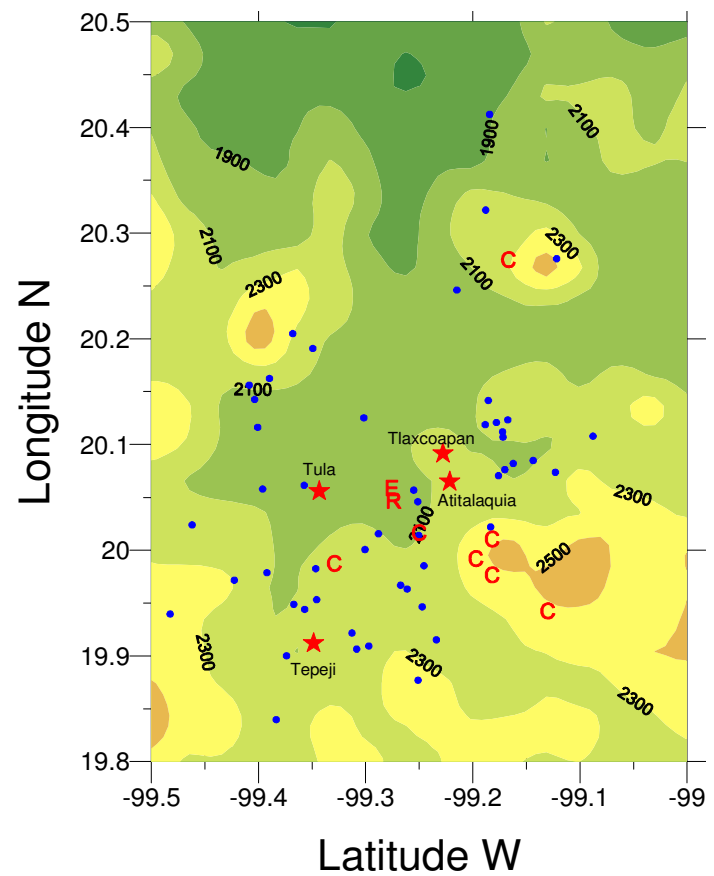

Fig. 1. Mezquital Valley study area. Symbols: dots, sampling sites; stars, main urban settlements; E, electricity power plant; R, petroleum refinery; $\mathrm{C}$, cement plants. The isoline numbers indicate topographic elevation $(\mathrm{m})$.

pollutant bioaccumulation was minimized by analyzing only the newest 3-4 pairs of leaves per shoot. Thus, the time period of environmental exposition was assumed to be similar among sites, probably representing one or two years.

\subsubsection{Metals}

The glass and Teflon material for sample digestion was cleaned by immersion in $10 \% \mathrm{HNO}_{3}(24 \mathrm{~h})$ followed by profuse rinsing with deionized water. The plant samples were oven-dried to constant weight $\left(70^{\circ} \mathrm{C}\right.$, three days) and ground to fine powder with agate mortar and pestle. A fraction of the powder (0.15-0.2 g per sample) was digested with $6.0 \mathrm{ml}$ $\mathrm{HNO}_{3}(65 \%$, Merck), $4.0 \mathrm{ml} \mathrm{HCl}$ (38\%, JT Baker, Ultrex II), and $0.2 \mathrm{ml} \mathrm{HF} \mathrm{(48 \% ,} \mathrm{JT} \mathrm{Baker,} \mathrm{Ultrex} \mathrm{II)} \mathrm{in} \mathrm{a} \mathrm{microwave}$ oven (Anton Paar, Multiwave 3000) using the "pine needles" program: phase I (power, $1400 \mathrm{~W}$; ramp, $10 \mathrm{~min}$; hold, $10 \mathrm{~min}$; fan 1), phase 2 (power, $0 \mathrm{~W}$; hold, $30 \mathrm{~min}$; fan 2). Digestion temperature was $180^{\circ} \mathrm{C}$. The digests were filtered with Whatman 4 paper and brought to $25 \mathrm{ml}$ with deionized water.

The elements were determined by inductively coupled plasma/optical emission spectrometry (ICP-OES, PerkinElmer, Optima $3200 \mathrm{DV}$ ) following the USEPA 6010C method (EPA, 2000). The sample injection flow was

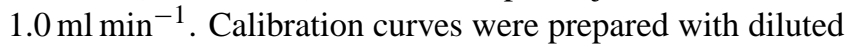
element standard solutions (High Purity). QC repeatability 
was checked up by injecting element mixtures (Ultra Scientific) every 10-15 samples. The percent recovery of seven certified elements in seven equally processed samples of the NIST 1575a standard reference material (trace elements in pine needles) was (mean \pm coefficient of variation): $\mathrm{Al}(102.2 \pm 2.0), \mathrm{Ca}(113.5 \pm 10.1), \mathrm{Fe}(117.3 \pm 7.5)$, $\mathrm{Mg}(84.8 \pm 13.9), \mathrm{P}(96.5 \pm 2.0), \mathrm{Zn}(83.0 \pm 5.1)$. The recovery of Ba was low $(35.8 \pm 6.4 \%)$, but was very good for In $(103.7 \pm 2.9 \%)$, which was added as surrogate from a $5.0 \mathrm{ppm}$ standard solution.

\subsubsection{PAH}

The samples were organically extracted in microwave oven and analyzed by high performance liquid chromatography (HPLC) for the 15 PAH listed in Table 1. All glassware and Teflon materials for sample preparation were cleaned with liquid detergent (Liqui Nox), running water and consecutive rinsing with bidistilled water, acetone and dichloromethane (DCM). Samples (5 to $8 \mathrm{~g}$, air-dry weight) were frozen with liquid nitrogen and ground to powder with ceramic mortar and pestle. A fraction of the powder $(0.25-0.5 \mathrm{~g})$ was ovendried $\left(90^{\circ} \mathrm{C}, 24 \mathrm{~h}\right)$ for dry weight determination and about $2.0 \mathrm{~g}$ were extracted in 10 -sample batches with $30 \mathrm{ml}$ DCM in microwave oven (CEM, model MarsX). The oven was programmed according to USEPA 3546 method: potency, $1200 \mathrm{~W}$; pressure, $100 \mathrm{psi}$; temperature, $115^{\circ} \mathrm{C}$; time, $15 \mathrm{~min}$; total extraction time, $30 \mathrm{~min}$; cooling, $2 \mathrm{~h}$. Each extraction batch included one pure DCM blank and one positive laboratory control sample (LCS). The LC samples were added $0.5 \mathrm{~g}$ of dehydrated and deactivated Cromosorb (60/80 mesh, Supelco, Inc; $400^{\circ} \mathrm{C}$ for $4 \mathrm{~h}$ ) as a surrogate for the vegetal matrix and $200 \mu \mathrm{l}$ of standard mixture containing $5 \mu \mathrm{g} \mathrm{ml}^{-1}$ of each target PAH (Chemservice). The extracts were filtered through Millipore membrane and concentrated to $1.0 \mathrm{ml}$ under a gentle stream of ultrapure nitrogen supplied with a nitroevaporator (8158, N EVAP111, Organomation Associates, Inc). The concentrates were cleaned with chromatographic glass columns $(40 \mathrm{~cm}$ length $\times 1.5 \mathrm{~cm}$ ID) filled with deactivated $\left(400^{\circ} \mathrm{C}\right.$ for $4 \mathrm{~h}$ ) alumina-silica-gel (USEPA 3610B and 3630C). The columns were packed from bottom to top with $1.0 \mathrm{~cm}$ silanized glass fiber (Alltech) humidified with DCM, $10 \mathrm{~g}$ alumina (Baker, Inc.), $3.0 \mathrm{~g}$ silica gel (60/200 mesh, Mallincroft) and $2.0 \mathrm{~g}$ anhydrous sodium sulfate (JT Baker) dissolved in DCM. Extra DCM $(30 \mathrm{ml})$ was added to the columns for final PAH separation. Eluates were captured in glass vials and concentrated to $1.0 \mathrm{ml}$ under ultrapure nitrogen. They were then changed into acetonitrile $(4.0 \mathrm{ml}$, Burdick \& Jackson), filtered with $0.2 \mu \mathrm{m}$ acrodiscs (Pall Gelman Laboratory), reconcentrated to $0.5 \mathrm{ml}$ with ultrapure nitrogen and stored at $-40^{\circ} \mathrm{C}$ in amber glass vials until analyses.

The extracts were analyzed with a liquid chromatograph (Agilent HP, 1100 series) equipped with Nucleosil column (Macherey-Nagel, $265 \mathrm{~mm}, 100-5 \mathrm{C} 18 \mathrm{PAH}$ ), automatic sample injector, and DAD and fluorescence detectors. The
Table 1. Target PAH and HPLC analytical parameters.

\begin{tabular}{llrr}
\hline PAH & $\begin{array}{l}\text { FLD } \\
\lambda e x-\lambda \mathrm{em}^{1} \\
(\mathrm{~nm})\end{array}$ & $\mathrm{RT}^{2}$ & $\mathrm{QL}^{3}$ \\
& $(\mathrm{~min})$ & $\left(\mu \mathrm{g} \mathrm{ml}^{-1}\right)$ \\
\hline Naphthalene, NAP & $275-350$ & 4.29 & 0.03 \\
Acenaphthylene, ACY & $275-350$ & 4.95 & 0.03 \\
Acenaphthene, ACE & $275-350$ & 6.75 & 0.01 \\
Fluorene, FLN & $275-350$ & 7.30 & 0.01 \\
Phenanthrene, PHE & $275-350$ & 8.59 & 0.01 \\
Anthracene, ANT & $275-450$ & 10.45 & 0.01 \\
Fluoranthene, FLT & $275-450$ & 11.94 & 0.01 \\
Pyrene, PYR & $275-410$ & 13.14 & 0.03 \\
Benzo $(a)$ anthracene, B $a \mathrm{~A}$ & $275-410$ & 17.29 & 0.03 \\
Chrysene, CHR & $275-410$ & 18.47 & 0.01 \\
Benzo $(b)$ fluoranthene, B $b \mathrm{~F}$ & $275-410$ & 21.32 & 0.01 \\
Benzo $(k)$ fluoranthene, B $b \mathrm{~F}$ & $275-410$ & 23.02 & 0.03 \\
Benzo $(a)$ pyrene, B $a \mathrm{P}$ & $275-410$ & 24.28 & 0.03 \\
Benzo $(g, h, i)$ perylene, B $g \mathrm{P}$ & $275-410$ & 27.56 & 0.01 \\
Indeno $(1,2,3-c d)$ pyrene, I $c d \mathrm{P}$ & $275-495$ & 29.01 & 0.03 \\
\hline
\end{tabular}

1 Fluorescence detector excitation (ex) and emission (em) wave length; ${ }^{2}$ retention time; ${ }^{3}$ Quantification limit.

analyses were done in 10-sample batches plus one blank and one positive control. A calibration curve per batch was developed with seven concentrations $\left(0.0625\right.$ to $\left.5.0 \mu \mathrm{g} \mathrm{ml}^{-1}\right)$ of stock acetonitrile solution containing $5 \mu \mathrm{g} \mathrm{ml}^{-1}$ of each target PAH. Samples were added $150 \mu 1$ of $4,4^{\prime}$-difluorobifenil (Chemservice) solution in acetonitrile $\left(4 \mu \mathrm{g} \mathrm{ml}^{-1}\right)$ as internal standard. Solvent A (methanol, 50\%; acetonitrile, 25\%; HPLC water, 25\%) was injected from 0 to $3 \mathrm{~min}$ and gradually exchanged by solvent B (acetonitrile) from 3 to $21 \mathrm{~min}$. Only this latter solvent was added from 21 to $35 \mathrm{~min}$. The injection volume was $5 \mu \mathrm{l}$; flux, $0.3 \mathrm{ml} \mathrm{min}^{-1}$; column temperature, $25^{\circ} \mathrm{C}$; wavelength (FLD: $275-495 \mathrm{~nm}$, Table 1; DAD: $230 \mathrm{~nm}$ ). The total time of analysis per sample extract was $30 \mathrm{~min}$. The method validation parameters were: linearity $\left(R^{2}>.98\right)$; accuracy and precision $(\mathrm{RSD}<3 \%)$; detection limit $\left(0.004 \mu \mathrm{g} \mathrm{ml}^{-1}\right)$ and quantification limits, depending on the compound, 0.01 to $0.03 \mu \mathrm{g} \mathrm{ml}^{-1}$ (Table 1).

\subsection{3 $\quad \delta^{13} \mathrm{C}$ and $\delta^{15} \mathrm{~N}$}

Air-dried samples (200-500 mg) were ground with cleaned ceramic mortar and pestle under liquid nitrogen, and dried at $80^{\circ} \mathrm{C}$ for $24 \mathrm{~h}$. The $\delta^{13} \mathrm{C}$ and $\delta^{15} \mathrm{~N}$ ratios were determined with a dual carbon and nitrogen analyzer coupled to a continuous flow isotope ratio mass spectrometer (Europa Scientific). Equipment precision was $0.1 \%$ for $\mathrm{C}$ and $0.2 \%$ for $\mathrm{N}$. The isotopic composition is defined by:

$\delta^{13} \mathrm{C}$ or $\delta^{15} \mathrm{~N}(\% o)=\left(R_{\text {sample }} / R_{\text {standard }}-1\right) \times 1000$

where $R$ is the sample or standard ratio of the heavy to the light isotope: ${ }^{13} \mathrm{C} /{ }^{12} \mathrm{C}$ and ${ }^{15} \mathrm{~N} /{ }^{14} \mathrm{~N}$. The V-PDB (Viena Pee Dee Belemnite) and atmospheric nitrogen were used as 
standards to determine $\delta^{13} \mathrm{C}$ and $\delta^{15} \mathrm{~N}$, respectively (Mariotti, 1974; Coplen, 1995).

\subsection{Statistics}

The raw site-pollutant data base was regionally summarized by simple central tendency and dispersion statistics. The geographical distribution of pollutants was explored by mapping with a geostatistical gridding method for irregularly spaced data (Surfer, Ver. 7.05, Kriging method) and comparing concentrations between and among MV areas with $t$ tests or ANOVA, as appropriate. Potential emission sources were explored by factor analyses (FA) with principal component extraction and normalized varimax rotation (Statistica, Ver. 6.0). Since 50 sampling sites was a small number of cases, FA was used conservatively. Only 20 pollutants were included in FA to keep a 2.5 site to variable ratio. The standardized median site values were used for FA. Pollutants excluded from this analysis had one or more of the following problems: they were not detected or below quantification levels at $\geq 8$ sampling sites (i.e., $16 \%$ of sites: $\mathrm{Pb}, \mathrm{Sb}$, $\mathrm{B} a \mathrm{~A}, \mathrm{~B} b \mathrm{~F}, \mathrm{~B} k \mathrm{~F}, \mathrm{~B} a \mathrm{P}$ and $\mathrm{I} c d \mathrm{P})$; high skewness (>2) and/or kurtosis ( $>7)$; strong deviation from normality even after log transformation (Shapiro-Wilk test); no significant correlation with any other pollutant, because they tended to form factors with single pollutants (e.g., Cd and $\mathrm{Cr}$ ), or contrarily, very high correlation $(r>0.9)$, which may lead to multicollinearity. All low and some medium molecular weight PAH, which predominantly disperse in the gas phase, were also excluded from FA (NAP, ACY, ACE, FLN, PHE, ANT and FLT). Finally, the pollutant selection for FA was aided by considering element signal to noise ratios (SNR), which relate the regional to the site variability, as defined by Wolterbeek et al. (1996), and the element enrichment factors (EF) calculated as

$\mathrm{EF}=\left(\mathrm{X}_{s} / \mathrm{Al}_{s}\right) /\left(\mathrm{X}_{r} / \mathrm{Al}_{r}\right)$

where $\mathrm{X}_{s}$ and $\mathrm{Al}_{s}$ are the sample element and aluminum concentrations (ppm), respectively; $\mathrm{X}_{r}$ and $\mathrm{Al}_{r}$ are the element and aluminum concentrations (ppm) in the main crustal rocks of MV: limestone, according to Lozano and Bernal (2005), and acidic igneous rocks, using averaged data from an internet data base by Surendra (2001).

\section{Results and discussion}

Mezquital Valley was biomonitored with $T$. recurvata to detect the regional dispersion trends and potential emission sources of airborne metals and PAH.

\subsection{Metals}

Table 2 summarizes the regional element concentrations in the biomonitor. Calcium was the most abundant element (regional mean, $1.3 \%$ on dry weight basis; $\min , 0.5 \%$; $\max$,
Table 2. Regional element concentrations in T. recurvata $\left(\mathrm{mg} \mathrm{kg}^{-1}\right)$.

\begin{tabular}{lrcccccccc}
\hline $\begin{array}{l}\text { Ele- } \\
\text { ment }\end{array}$ & $\mathrm{N}$ & $\mathrm{n}$ & Mean & Median & Range & $\begin{array}{l}\mathrm{CV} \\
(\%)\end{array}$ & SNR & $p(r)$ & $p(\log )$ \\
\hline $\mathrm{Al}$ & 150 & 50 & 4155 & 3969 & $290-11900$ & 41.1 & 4.5 & \\
$\mathrm{Ba}$ & 150 & 50 & 38.1 & 33.2 & $8.9-131$ & 51.0 & 4.1 & $>.05$ \\
$\mathrm{Ca}$ & 149 & 50 & 12556 & 10190 & $2883-46780$ & 55.2 & 7.3 & \\
$\mathrm{Cd}$ & 150 & 50 & 2.2 & 1.9 & $0.9-6.5$ & 42.7 & 2.1 & $>.05$ \\
$\mathrm{Cr}$ & 139 & 49 & 6.1 & 4.5 & $0.8-40.4$ & 96.3 & 6.1 & $>.05$ \\
$\mathrm{Cu}$ & 150 & 50 & 7.0 & 5.9 & $2.0-48.4$ & 71.6 & 3.5 & \\
$\mathrm{Fe}$ & 149 & 50 & 1579 & 1444 & $401-4368$ & 41.1 & 3.5 & $>.05$ \\
$\mathrm{~K}$ & 150 & 50 & 7568 & 7559 & $1398-16380$ & 33.3 & 2.5 & $>.05$ & \\
$\mathrm{Li}$ & 150 & 50 & 18.1 & 17.0 & $6.0-34.0$ & 24.8 & 3.2 & $>.05$ \\
$\mathrm{Mg}$ & 150 & 50 & 2906 & 2815 & $868-6285$ & 33.8 & 2.7 & $>.05$ \\
$\mathrm{Mn}$ & 149 & 50 & 80.3 & 75.2 & $14.2-327.4$ & 39.4 & 4.3 & $>.05$ \\
$\mathrm{Mo}$ & 145 & 47 & 4.0 & 4.0 & $0.3-28.6$ & 76.6 & 5.5 & \\
$\mathrm{Na}$ & 149 & 50 & 3236 & 3046 & $424-10280$ & 57.6 & 6.1 & $>.05$ & \\
$\mathrm{Ni}$ & 123 & 50 & 15.9 & 14.0 & $1.6-44.2$ & 60.4 & 4.5 & \\
$\mathrm{P}$ & 150 & 50 & 501 & 486 & $163-1642$ & 45.1 & 3.8 & $>.05$ \\
$\mathrm{~Pb}$ & 86 & 31 & 33.1 & 28.6 & $1.4-226$ & 92.0 & 3.6 & $>.05$ \\
$\mathrm{Sb}$ & 25 & 9 & 4.0 & 2.9 & $0.2-25.4$ & 124.3 & 3.6 & & \\
$\mathrm{Sr}$ & 148 & 50 & 30.5 & 28.4 & $1.9-83.2$ & 44.8 & 2.8 & \\
$\mathrm{Ti}$ & 150 & 50 & 196 & 177 & $58.0-532$ & 42.8 & 2.8 & \\
$\mathrm{~V}$ & 150 & 50 & 43.4 & 29.7 & $6.5-220$ & 86.8 & 5.5 & \\
$\mathrm{Zn}$ & 150 & 50 & 41.9 & 36.4 & $3.7-192$ & 57.0 & 4.0 & $>.05$ \\
\hline & & & & & & & & \\
\hline
\end{tabular}

$\mathrm{N}$, number of samples; $\mathrm{n}$, number of sampling sites with quantifiable amount of elements; $\mathrm{CV}$, coefficient of variation; SNR, mean signal to noise ratio; $p(r)$ and $p(\log )$, probability associated to Shapiro-Wilks normality test for raw and $\log _{10}$ transformed data, respectively; empty cells, non-normal distribution.

4.5\%). This indicated high regional exposure to limestone dust at MV, which is exacerbated by the cement industry. Predominance of $\mathrm{Ca}$ in lichen biomonitors growing near a cement plant was recently reported by Branquinho et al. (2008). They considered this element as the best indicator for cement-dust. Other major geological elements followed $\mathrm{Ca}$ in abundance $(\%): \mathrm{K}(0.76)>\mathrm{Al}(0.42)>\mathrm{Na}(0.34)>$ $\mathrm{Mg}(0.29)>\mathrm{Fe}(0.17)>\mathrm{P}(0.05)>\mathrm{Ti}(0.02)>\mathrm{Mn}(0.008)$.

The trace elements constituted individually less than $0.005 \%$ of the $T$. recurvata dry biomass: $\mathrm{V}(0.0044)>$ $\mathrm{Zn}(0.0042)>\mathrm{Ba}(0.0038)>\mathrm{Pb}(0.0034)>\mathrm{Sr}(0.0031)>$ $\mathrm{Li}(0.0018)>\mathrm{Ni}(0.0016)>\mathrm{Cu}(0.0007)>\mathrm{Cr}(0.0006)>$ $\mathrm{Sb}(0.0005)>\mathrm{Mo}(0.0004)>\mathrm{Cd}(0.0002)$. The prevalence of $\mathrm{V}$, an element typically abundant in crude oils (Bairwise, 1990), can be attributable to emissions from the major industrial users of petroleum fuels at MV. This will be detailed later.

At the gross level of data reduction in Table 2, the element concentrations in $T$. recurvata reflected the composition of the MV acidic crustal rocks and agriculture soils (Fig. 2). According to this figure, there was a closer chemical similarity between the biomonitor and the igneous rocks $\left(R^{2}=0.86\right)$ than for soils $\left(R^{2}=0.78\right)$ and limestone $\left(R^{2}=0.64\right)$. Thus, a high proportion of the spatial element variability in the biomonitor could be expected to derive from these sources.

Most measured elements had higher mean concentrations than reported for other Tillandsia biomonitors in other US and Latin American areas. This is shown in Table 3 by the element concentration ratios between MV and other countries 

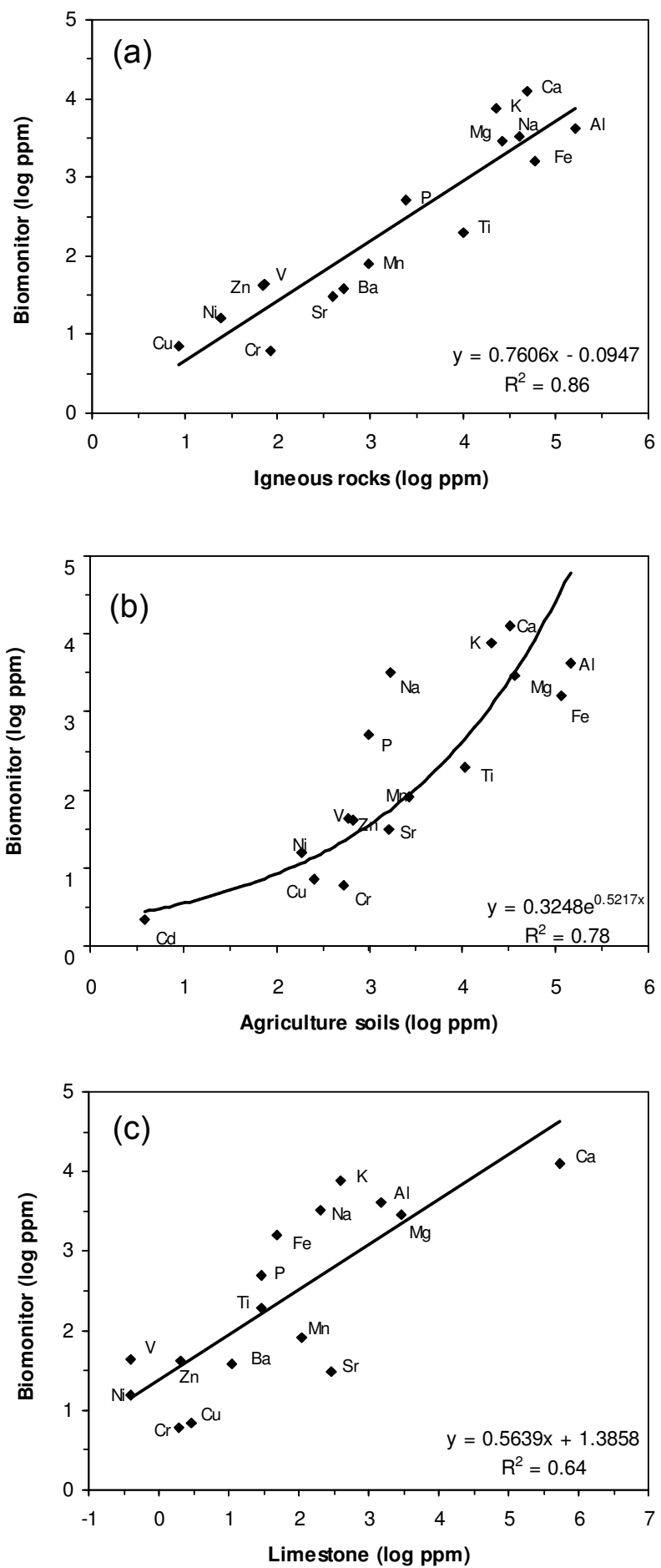

Fig. 2. Elements in T. recurvata and crustal/soil sources at Mezquital Valley $\left(\log _{10}\right.$ transformed mean values, $\left.\mathrm{ppm}=\mathrm{mg} \mathrm{kg}^{-1}\right)$. Geochemical data: acidic igneous rocks, calculated from VermaSurendra (2001); agricultural soils, median values among FloresDelgadillo et al. (1992), Hernández-Silva et al. (1994), Huerta et al. (2002), Lucho-Constantino et al. (2005), and Siebe (1994); limestone (Lozano and Bernal, 2005).
(MV:OT). This ratio was $\geq 2$ in 25 out of 44 cases in Table 3 , which implies $\geq 100 \%$ higher bioaccumulation by the Mexican Tillandsia. The difference was larger for anthropogenic elements such as $\mathrm{Ni}, \mathrm{Pb}$ and $\mathrm{V}$, whose respective concentrations at MV were 79, 66 and up to 43 times higher than measured in Tillandsia biomonitors from Argentina (Wannaz et al., 2006a, b). Assuming similar interspecies ability to capture and retain airborne metals, such differences indicate that regional atmospheric deposition levels at MV are at least as high as indicated by those ratios. The MV:OT ratio was $<1.0$ only in 11 cases; i.e., lower element concentration at MV (Table 3). Most of them involved $\mathrm{Cu}$ and Zn biomonitored within urban/industrial areas at São Paulo, Brazil (Figuereido et al., 2007), Cali and Medellin, Colombia (Schrimpff, 1984). This is attributable to the fewer rural sites included in these studies, which are usually less exposed to anthropogenic emissions and tend to lower the regional mean estimates.

\subsection{PAH}

Table 4 summarizes the regional concentration and variability of PAH in the biomonitor. The sum of quantified PAH per site ranged from 143 to $2568 \mathrm{ng} \mathrm{g}^{-1}$, with regional mean and median equal to 572 and $439 \mathrm{ng} \mathrm{g}^{-1}$, respectively, indicating a data distribution skewed to the right. Apart from PHE and CHR, which were lognormally distributed, the rest of PAH had neither normal nor lognormal distributions. The regional variability of PAH depended on the compound, ranging from $58 \%$ (ACY) to $165 \%$ (FLN). The medium molecular weight PAH (MMW: PHE, ANT, FLT, PYR, B $a$ A and CHR) was the most abundant group, representing $64.5 \%$ of the total measured PAH. The low molecular weight PAH (LMW: NAP, ACY, ACE and FLN) constituted $28.1 \%$, and the high molecular weight (HMW: $\mathrm{B} b \mathrm{~F}, \mathrm{~B} k \mathrm{~F}, \mathrm{~B} a \mathrm{P}, \mathrm{B} g h i \mathrm{P}$ and $\mathrm{I} c d \mathrm{P}$ ) only $7.3 \%$. The relatively low amount of the most hazardous PAH group (HMW) deserves further research to be explained. Hypothetically, it may be attributed to photodegradation enhanced by the high solar irradiation rates received in this tropical semiarid region and the scarce protection from it provided by the very open local vegetation.

The most frequent PAH were FLT, FLN, PHE and PYR, which were present at all sampled sites, followed by CHR, NAP and BghiP, which were missed only at one or two sites. Most HMW PAH had low to very low frequencies. For instance, $\mathrm{B} a \mathrm{P}$ had quantifiable levels at only nine sites, and $\mathrm{B} a \mathrm{~A}, \mathrm{~B} k \mathrm{~F}$ and $\mathrm{I} c d \mathrm{P}$ at the two sites closest to the petroleum refinery and the electrical power plant (Fig. 1). The most abundant compounds were FLT $(24.2 \%$ of total quantified PAH, regional average), PHE (17.1\%) and NAP (10.4\%).

Table 5 compares the mean total PAH in $T$. recurvata at MV with other biomonitoring studies using Tillandsia. Such comparisons are, however, limited by the several factors affecting the total sum of PAH of each study; e.g., the number and type of measured compounds, the biomonitor's ability to 
Table 3. Elements in other Tillandsia biomonitors from other countries (OT) respect to T. recurvata at Mezquital Valley, Mexico (MV). Units: $\mathrm{mg} \mathrm{kg}^{-1}$; values in parentheses, MV:OT ratio.

\begin{tabular}{|c|c|c|c|c|c|c|c|}
\hline Element & MV & Argentina $^{1}$ & Argentina $^{2}$ & Brazil $^{3}$ & Colombia $^{4}$ & Colombia $^{5}$ & $\mathrm{US}^{6}$ \\
\hline $\mathrm{Al}$ & 4155 & & & $1112(3.7)$ & & & \\
\hline $\mathrm{Ba}$ & 38.1 & & & $36.8(1)$ & & & \\
\hline $\mathrm{Ca}$ & 12556 & & & $3312(3.8)$ & & & $4160(3.0)$ \\
\hline $\mathrm{Cd}$ & 2.2 & & & & $0.4(5.3)$ & $0.82(2.6)$ & \\
\hline $\mathrm{Cr}$ & 6.1 & & & $2.2(2.8)$ & & & \\
\hline $\mathrm{Cu}$ & 7.0 & $0.9(7.8)$ & $0.9(7.0)$ & $19.3(0.4)$ & $52.7(0.1)$ & $30.5(0.2)$ & $7.1(1.0)$ \\
\hline $\mathrm{Fe}$ & 1579 & $223(7.1)$ & $257(6.1)$ & 1144 (1.4) & & & $575(2.7)$ \\
\hline $\mathrm{K}$ & 7568 & & & $5890(1.3)$ & & & $2550(3.0)$ \\
\hline $\mathrm{Mg}$ & 2906 & & & 2025 (1.4) & & & $414(7.0)$ \\
\hline $\mathrm{Mn}$ & 80.3 & $22.6(3.6)$ & 22.3 (3.6) & $174(0.5)$ & & & $52.8(1.5)$ \\
\hline $\mathrm{Na}$ & 3236 & & & $1923(1.7)$ & & & \\
\hline $\mathrm{Ni}$ & 15.9 & $0.2(79.4)$ & $0.2(79.4)$ & & $11.9(1.3)$ & $52.8(0.3)$ & \\
\hline $\mathrm{Pb}$ & 33.1 & $0.5(66.2)$ & $0.5(66.2)$ & & $40.6(0.8)$ & $26.3(1.3)$ & \\
\hline $\mathrm{Sb}$ & 4.0 & & $0.5(8.0)$ & & & & \\
\hline V & 43.4 & $1.0(43.4)$ & $1.1(39.5)$ & $2.7(16.1)$ & & & \\
\hline $\mathrm{Zn}$ & 41.9 & $4.0(10.5)$ & $3.8(11.0)$ & $111(0.4)$ & $119(0.4)$ & $379(0.1)$ & $73.5(0.6)$ \\
\hline
\end{tabular}

${ }^{1}$ Wannaz et al. (2006a), T. capillaris; ${ }^{2}$ Wannaz et al. (2006b), T. permutata ${ }^{3}$ Figuereido et al. (2007), T. usneoides, average value for the two-months transplanting period presenting the maximum concentration, excluding the control site, ${ }^{4,5}$ Schrimpff (1984), Cali and Medellín cities, respectively; ${ }^{6}$ Husk et al. (2004), T. usneoides in Florida, samples recollected in 1998. Empty cells: data not reported.

capture and retain them, and design aspects of the biomonitoring studies; for instance, number and type of sampling sites, length of exposure and sampling strategy (in situ vs. transplanted samples). No difference was clear between the total PAH at MV and one heavily polluted site at Mexico City measured by Hwang et al. (2003) with pine needles, a morphologically and physiologically different receptor. The mean total PAH reported for T. usneoides from polluted sites in Río de Janeiro (De Sousa et al., 2007) doubled the mean value at MV. Nevertheless, the most polluted MV sites had similar or slightly different total PAH (1284$1748 \mathrm{ng} \mathrm{g}^{-1}$ ) than the polluted sites at Rio de Janeiro, and no MV site had lower total PAH than unpolluted Brazilian sites ( 93 to $175 \mathrm{ng} \mathrm{g}^{-1}$ ). Levels of total PAH at MV were $70 \%$ to $140 \%$ higher than recorded for two different Tillandsia species transplanted from Costa Rica into downtown Florence, Italy, for eight months (Brighina et al., 2002).

\section{$3.3 \delta^{13} \mathrm{C}$ and $\delta^{15} \mathrm{~N}$}

The spatial patterns of the $\delta^{13} \mathrm{C}$ and $\delta^{15} \mathrm{~N}$ in T. recurvata reflected quite well the main land uses at MV. Interestingly, these ratios showed that this epiphyte is naturally less discriminatory against ${ }^{13} \mathrm{C}$ and more discriminatory against ${ }^{15} \mathrm{~N}$ than most terrestrial plants.

The regional $\delta^{13} \mathrm{C}$ ratio (mean, $-14.6 \%$; min, $-15.7 \%$; $\max ,-13.7 \%$ ) was similar to known values for this species $(-15.3 \%$ to $-13.2 \%$, Martin, 1994) and within range for Tillandsia with crassulacean acid metabolism (CAM; $\delta^{13} \mathrm{C}>-20 \%$, Crayn et al., 2004); i.e., plants which fix $\mathrm{CO}_{2}$
Table 4. Regional PAH concentrations $\left(\mathrm{ng} \mathrm{g}^{-1}\right)$ in T. recurvata.

\begin{tabular}{lcccccr}
\hline HAP & N & $\mathrm{n}$ & Mean & Median & Range & $\begin{array}{r}\text { CV } \\
(\%)\end{array}$ \\
\hline NAP & 141 & 49 & 82.3 & 49.6 & $6.0-607$ & 122.8 \\
ACY & 85 & 40 & 88.6 & 78.8 & $10.2-292$ & 61.9 \\
ACE & 51 & 32 & 19.6 & 13.4 & $1.1-87.0$ & 95.6 \\
FLN & 129 & 50 & 37.6 & 21.4 & $7.2-386$ & 134.6 \\
PHE & 150 & 50 & 136 & 114 & $9.9-624$ & 60.3 \\
ANT & 92 & 42 & 9.0 & 7.1 & $1.7-27.0$ & 63.0 \\
FLT & 150 & 50 & 192 & 72.2 & $19.3-1674$ & 164.9 \\
PYR & 148 & 50 & 25.9 & 22.1 & $0.03-158$ & 88.0 \\
B $a$ A & 2 & 2 & 12.8 & 12.8 & $0.2-25.4$ & 139.7 \\
CHR & 127 & 49 & 22.5 & 18.2 & $1.9-92.9$ & 72.6 \\
B $b$ F & 75 & 40 & 18.3 & 13.2 & $0.1-131$ & 118.0 \\
B $k$ F & 2 & 2 & 13.5 & 13.5 & $1.7-25.3$ & 123.6 \\
B $a$ P & 12 & 9 & 41.7 & 39.9 & $2.4-87.6$ & 58.2 \\
B $g h$ P & 112 & 48 & 28.1 & 22.5 & $4.0-134$ & 73.7 \\
I $c d$ P & 2 & 2 & 67.0 & 67.0 & $22.2-112$ & 94.4 \\
LMW & 150 & 50 & 164 & 128 & $12.4-738$ & 81.2 \\
MMW & 150 & 50 & 376 & 261 & $74.1-2131$ & 96.8 \\
HMW & 122 & 50 & 42.5 & 32.8 & $0.1-250$ & 85.0 \\
$\Sigma$ HAPs & 150 & 50 & 572 & 439 & $142.6-2568$ & 76.7 \\
\hline
\end{tabular}

$\mathrm{N}$, number of samples; $\mathrm{n}$, number of sampling sites with quantifiable amount of $\mathrm{PAH} ; \mathrm{CV}$, coefficient of variation. 
Table 5. Mean PAH concentration $\left(\mathrm{ng}^{-1}\right)$ in $T$. recurvata at Mezquital Valley (MV) and Tillandsia in other countries (OT). Values in parentheses are the MV:OT ratio.

\begin{tabular}{|c|c|c|c|c|c|c|}
\hline \multirow[t]{2}{*}{ HAPs } & \multirow[t]{2}{*}{ MV } & \multirow[t]{2}{*}{$\begin{array}{r}\text { Mexico } \\
\text { City }{ }^{1}\end{array}$} & \multicolumn{2}{|c|}{$\begin{array}{c}\text { Sao Paulo, } \\
\text { Brazil }^{2}\end{array}$} & \multicolumn{2}{|c|}{$\begin{array}{l}\text { Florence, } \\
\text { Italy }^{3}\end{array}$} \\
\hline & & & $\begin{array}{r}\text { Polluted } \\
\text { sites }\end{array}$ & $\begin{array}{r}\text { Unpolluted } \\
\text { sites }\end{array}$ & $\begin{array}{l}\text { T. caput- } \\
\text { medusae }\end{array}$ & T. bulbosa \\
\hline NAP & 82.3 & & $70.7(1.2)$ & $11.4(7.2)$ & & \\
\hline ACY & 88.6 & 8.3 (10.7) & $10.2(8.7)$ & $1.4(63.3)$ & $23.4(3.8)$ & $55.1(1.6)$ \\
\hline $\mathrm{ACE}$ & 19.6 & $1.7(11.5)$ & $13.7(1.4)$ & $8.6(2.3)$ & $53.6(0.4)$ & $53.9(0.4)$ \\
\hline FLN & 37.6 & & $24.6(1.5)$ & $9.5(4.0)$ & $4.0(9.4)$ & $112.1(0.3)$ \\
\hline PHE & 136 & $15.8(8.6)$ & $198.2(0.7)$ & $18.6(7.3)$ & & \\
\hline ANT & 9.0 & $2.39(3.8)$ & $23.3(0.4)$ & $1.5(6.0)$ & $6.9(1.3)$ & $14.0(0.6)$ \\
\hline FLT & 192 & $66.9(2.9)$ & $211.5(0.9)$ & $20.1(9.6)$ & & \\
\hline PYR & 25.9 & $118(0.2)$ & $145.1(0.2)$ & $14.2(1.8)$ & & \\
\hline $\mathrm{B} a \mathrm{~A}$ & 12.8 & $11.6(1.1)$ & $41.9(0.3)$ & $3.9(3.3)$ & $24.5(0.5)$ & $10.8(1.2)$ \\
\hline CHR & 22.5 & $49.8(0.5)$ & $119.4(0.2)$ & $18.3(1.2)$ & $34.9(0.6)$ & $18.5(1.2)$ \\
\hline $\mathrm{B} b+k \mathrm{~F}$ & 31.8 & $47.2(0.7)$ & $111.6(0.3)$ & $15.9(2.0)$ & & \\
\hline $\mathrm{B} a \mathrm{P}$ & 41.7 & $9.2(4.5)$ & $72.7(0.6)$ & $4.0(10.4)$ & $8.26(5.0)$ & $35.0(1.2)$ \\
\hline $\mathrm{B} g h i \mathrm{P}$ & 28.1 & $39.7(0.7)$ & $29.3(1.0)$ & $5.0(5.6)$ & $28.2(1.0)$ & \\
\hline $\mathrm{I} d c \mathrm{P}$ & 67.0 & $28.2(2.4)$ & $31.1(2.2)$ & $3.9(17.2)$ & $33.2(2.0)$ & $12.4(5.4)$ \\
\hline$\Sigma$ PAH & 572 & $563(1.0)$ & $1067(0.5)$ & $138(4.1)$ & $238(2.4)$ & $330(1.7)$ \\
\hline
\end{tabular}

${ }^{1}$ Hwang et al. (2003): measurements in Pinus maximartinezii needles at one site with vehicle/industrial emissions. ${ }^{2}$ After de Souza Pereira et al. (2007): average summer and winter measurements in T. usneoides. ${ }^{3}$ Brighigna et al. (2002): eight-month transplanting study at an urban site. Empty cells: data not reported.

predominantly at night as a water-saving adaption to arid environs (Pierce et al., 2002). This ratio was the most homogeneous of the measured variables. It varied only $2 \%$ o throughout MV (CV, 9.0\%). Its less negative values occurred at the predominantly rural NW sector of the valley $\left(\delta^{13} \mathrm{C}=-14.3 \% \circ \pm 0.13\right.$, mean \pm standard error $)$, being on average $0.6 \%$ higher than at the industrialized SE sector $(-14.9 \% \circ \pm 0.12 ; p<0.006$ from one-way ANOVA by sectors). This suggests that $T$. recurvata has a "background" $\delta^{13} \mathrm{C}$ signature similar to values recorded at the NW sector of MV (-14.3\%o, on average).

The $\delta^{13} \mathrm{C}$ values of $T$. recurvata decreased from the rural periphery of MV to the core industrial area, from values $\geq-14.5 \%$ o to $\leq-15 \%$ o (Fig. 3a). This negative shift reflected the increased emissions of ${ }^{13} \mathrm{C}$-depleted compounds from industrial fossil fuel combustion. The crude oils processed there have an average $\delta^{13} \mathrm{C}=-27 \%$, as inferred from available data for Mexican petroleum (e.g., Macko and Parker, 1983; Prinzhofer et al., 2000); i.e., 12.4\%o more negative than the mean value for $T$. recurvata. The effect from petroleum sources was further recognized by the regional correlation of $\delta^{13} \mathrm{C}$ with the $\mathrm{Ni} / \mathrm{V}$ ratio $(r=0.39, p=0.01)$, which was even closer $(r=0.70, p=0.001)$ when considering only the sampling sites along a belt transect in the predominant wind direction (NE-SW). Since Ni and V are the predominant trace metals in crude oils and keep relatively constant mutual proportions, their ratios $(\mathrm{Ni} / \mathrm{V}$ or $\mathrm{V} / \mathrm{Ni})$ are used for geochemical classification of crude oils (Bairwise, 1990) and as environmental indicators for petroleum sources (Ganor et al.,
1988). Figure 4 illustrates the parallel pattern followed by $\delta^{13} \mathrm{C}$ and Ni/V along a NE-SW transect, including a sharp decline at the closest downwind sites from the main petroleum sources $(\mathrm{km} 0)$. The regional mean $\mathrm{Ni} / \mathrm{V}$ for $T$. recurvata was $0.49 \pm 0.29(\mathrm{n}=50)$. The lower $(<0.20)$ and higher values $(>0.80)$ of this ratio occurred, respectively, near and far from the petroleum facilities. The Mexican crude oils used at $\mathrm{MV}$ have $\mathrm{Ni} / \mathrm{V}$ values ranging from 0.07 to 0.24 , and 0.17 on average, calculated from data by Castro and Vazquez (2009) and Espinosa Pena et al. (1996). Thus, the biomonitor tended to acquire $\mathrm{Ni} / \mathrm{V}$ values similar to crude oil at the sites more exposed to petroleum combustion emissions (Fig. 4).

The spatial pattern of $\delta^{15} \mathrm{~N}$ reflected clearly the agriculture, industrial and rural land uses at MV. The regional mean was $-3.0 \%$ ( $\min ,-9.9 \%$; $\max , 3.3 \%$ ), which represented a $6 \%$ to $9.6 \%{ }^{15} \mathrm{~N}$ enrichment respect to other Mexican atmospheric Tillandsia from less polluted habitats $\left(\delta^{15} \mathrm{~N}=-9.0 \% 0\right.$ to $-12.6 \%$, Hietz and Wanek, 2003; Hietz et al., 1999). The lowest, probably "background" signature for $T$. recurvata, occurred at the rural SW corner of $\mathrm{MV}\left(\delta^{15} \mathrm{~N} \approx-7.0 \%\right.$ ) Since the $\delta^{15} \mathrm{~N}$ of land plants range roughly from $-7 \%$ to +9\%o (Kelly et al., 2005), this Tillandsia belongs to the most discriminative plants against ${ }^{15} \mathrm{~N}$. This suggests that it could rely on biologically usable atmospheric compounds with low $\delta^{15} \mathrm{~N}$, such as gaseous $\mathrm{NH}_{3}$ and its derivative aerosol $\mathrm{NH}_{4}^{+}$(Krupa, 2003). Another contributing factor may be a symbiotic association with bacteria able to convert atmospheric ${ }^{14} \mathrm{~N}_{2}$ into usable salts for $T$. recurvata. Puente and Bashan (1994) documented the occurrence of such bacteria in Mexican T. recurvata, but their function needs to be proven.

The T. recurvata $\delta^{15} \mathrm{~N}$ pattern at MV changed from positive $(>3.0 \%$ o $)$ to negative $(<-6.0 \%$ ) along the predominant wind direction (NE-SW, Fig. 3b). The most positive to slightly negative values occurred at the NNE sector of the valley, near agriculture and industrial/urban areas, whereas the most negative were recorded at the farther WSW rural sites. Similarly high to low plant $\delta^{15} \mathrm{~N}$ spatial contrasts have been documented for other industrial/urban or agriculture areas respect to rural/remote locations (Gerdol et al., 2002; Jung et al., 1997; Pearson et al., 2000; Solga et al., 2005). Such contrasts are attributed in general to the higher $\mathrm{N}$ emission/deposition by human activities in the former areas, an explanation that finds support from the positive correlations often observed between the plant $\delta^{15} \mathrm{~N}$ and the total $\mathrm{N}$ deposition (e.g., Pardo et al., 2007; Skinner et al., 2006). Two major, probably supplementary, hypotheses have been proposed about what causes the higher plant $\delta^{15} \mathrm{~N}$ at the urban/industrial areas: a) increased exposure to some oxidized $\mathrm{N}$ species $\left(\mathrm{NO}_{\mathrm{x}}\right)$ from fossil fuel combustion, and $\mathrm{b}$ ) fractionating losses of the lighter ${ }^{14} \mathrm{~N}$ compounds from the plants by leaching or nitrification processes with subsequent concentration of ${ }^{15} \mathrm{~N}$ in the remaining $\mathrm{N}$ pools (Jung et al., 1997). Solga et al. (2005) reported a $\delta^{15} \mathrm{~N}$ spatial difference between mosses near agriculture areas (lower values) 


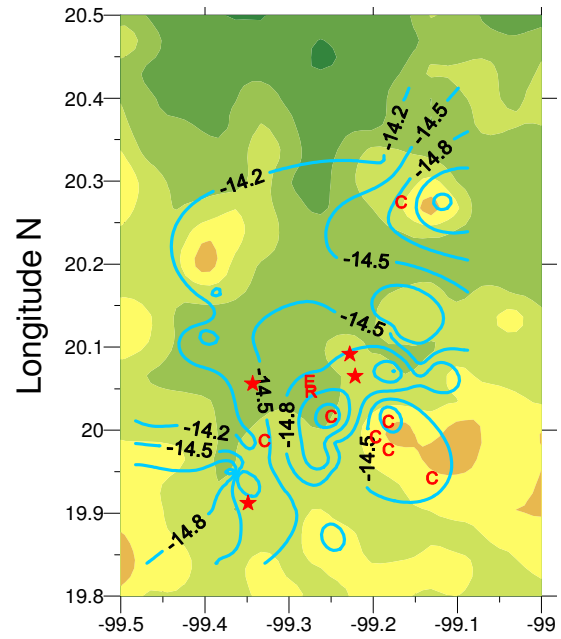

(a)

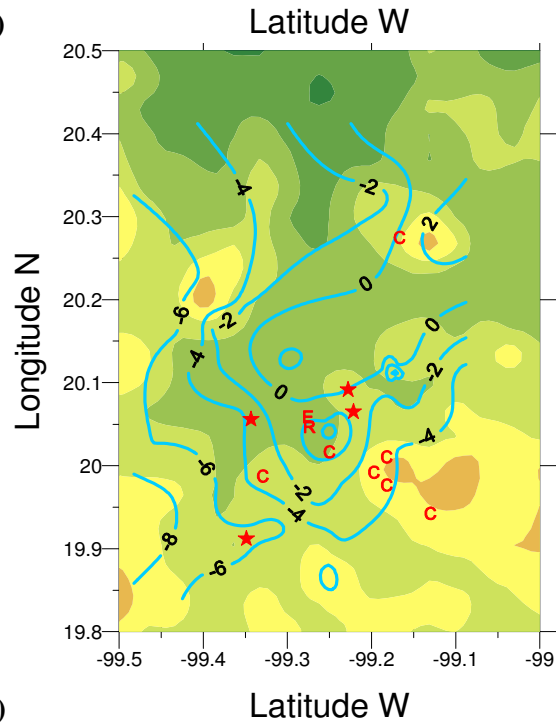

(b)

Latitude W

Fig. 3. Spatial distribution of the natural T. recurvata $\delta^{13} \mathrm{C}(\mathbf{a})$ and $\delta^{15} \mathrm{~N}(\mathbf{b})$ isotopic ratios (per mil, \%o) at Mezquital Valley.

and rural environs (higher values) negatively correlated with the $\mathrm{NH}_{4}^{+}: \mathrm{NO}_{3}^{-}$ratio of the bulk $\mathrm{N}$ deposition. This implies that increasing the proportion of $\mathrm{NO}_{3}^{-}$and compounds with high $\delta^{15} \mathrm{~N}$, like $\mathrm{N}_{2} \mathrm{O}(+6.7$ to $+7.0 \%$, Brenninkmeijer et al., 2003), would shift positively this plant ratio. The same effect would result by lowering the proportion of $\mathrm{NH}_{4}^{+}$and other ${ }^{15} \mathrm{~N}$-depleted compounds.

Although there may be a variety of $\mathrm{N}$ atmospheric compounds contributing to the T. recurvata $\delta^{15} \mathrm{~N}$ spatial pattern, specifying which of them accounted for it was beyond the reach of this survey. It can be, however, hypothesized that the higher $\delta^{15} \mathrm{~N}$ values near the agriculture areas may be related to the heavy use of untreated wastewater for irrigation. There are no $\delta^{15} \mathrm{~N}$ data for this water, but it is reasonable to assume high positive values, as reported elsewhere for wastewater $\left(\delta^{15} \mathrm{~N}=+10 \%\right.$ to $+22 \%$ ) . Soils and plants exposed to such ${ }^{15} \mathrm{~N}$-enriched water tend to acquire high $\delta^{15} \mathrm{~N}$

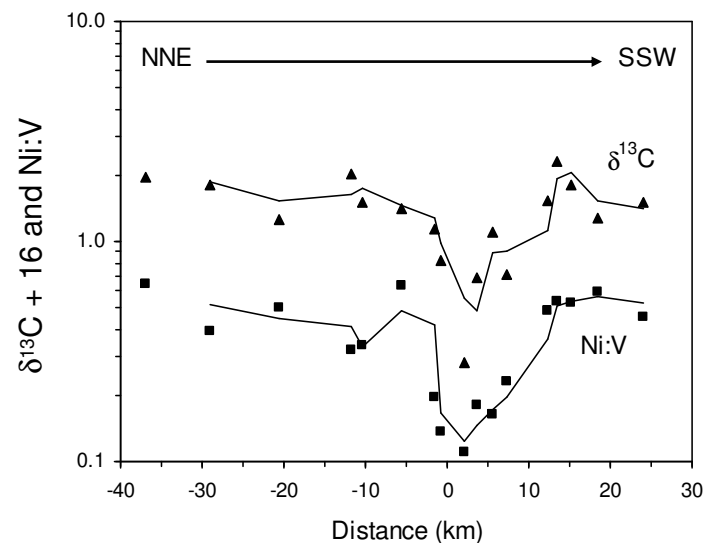

Fig. 4. Median $\delta^{13} \mathrm{C}$ (triangles) and $\mathrm{Ni}: \mathrm{V}$ ratios (squares) in T. recurvata at sites along a transect oriented with the predominant wind direction at Mezquital Valley (arrow). The main petroleum combustion sources are located at $\mathrm{km} 0$. The $\delta^{13} \mathrm{C}$ values were added 16 to allow the logarithmic transformation of the y-axis. The fitting lines are two-period running means.

values (Cole et al., 2004; Wigand et al., 2007). This is most likely the case at MV, where agriculture soils have a net positive $\mathrm{N}$ balance despite the substantial loss that may occur by volatilization from the open wastewater channels and during irrigation (Siebe, 1998). However, it can be hypothesized that gaseous and particulate emissions of compounds with high $\delta^{15} \mathrm{~N}$ (e.g., $\mathrm{N}_{2} \mathrm{O}$ and $\mathrm{NO}_{3}^{-}$, respectively) from those channels and soils are large enough to convert the naturally negative $\delta^{15} \mathrm{~N}$ of $T$. recurvata into positive values. Recent, spatially limited measurements (5 ha) on the emissions of $\mathrm{N}_{2} \mathrm{O}$ from local agriculture soils showed rates varying from $0.01-0.04 \mathrm{mg} \mathrm{m}^{-2} \mathrm{~h}^{-1}$ before irrigation with wastewater to $3.4 \mathrm{mg} \mathrm{m}^{-2} \mathrm{~h}^{-1}$ after irrigation, which are similar to fluxes from artificially fertilized soils (González-Méndez, et al. 2008). Other regional activities, like burning agriculture debris, may also contribute with high ${ }^{15} \mathrm{~N}$ emissions.

The $\delta^{15} \mathrm{~N}$ values at the core industrial area were similar to those at agriculture sites $(0 \%$ o to $+3 \%$ ). This could be due both to in situ $\mathrm{NO}_{\mathrm{x}}$ emissions from fossil fuel combustion sources (signaled with C, E and R in Fig. 3b) and to downwind transport of ${ }^{15} \mathrm{~N}$-enriched compounds from the main agriculture areas located immediately to the north of the industrial park.

\subsection{Distribution of pollutants and identification of major emission sources}

Some insights on the element spatial dispersion at MV can be derived from their regional variability in the biomonitor (Table 2). The average coefficient of variation was $58 \%$ and ranged from $25 \%(\mathrm{Li})$ to $124 \%(\mathrm{Sb})$. The elements with lower variability, such as the same $\mathrm{Li}$ and $\mathrm{K}(33 \%)$ were in general more homogeneously distributed throughout the region than those more variable (e.g., V, 87\%, Cr, 96\%). The 
former elements are more likely to be emitted by widely distributed sources; e.g., soil or crustal rocks, whereas the latter ones may derive from localized emission sources.

In looking for general spatial patterns at MV, the predominantly agricultural north was compared to the industrial south using the median site concentrations and straight $t$-tests. Eleven elements (Al, Ba, Ca, Fe, Mg, Mo, Ni, Sr, Ti, V and Zn) plus CHR and PYR had 18 to $214 \%$ higher concentrations at the industrial area $(p<0.05$, Table 6$)$. None was significantly more concentrated at the agricultural north. Such spatial difference is partially illustrated in Fig. 5. This figure plots the site normalized median concentration of $\mathrm{Ca}, \mathrm{CHR}$, PYR and $\mathrm{V}$ within a belt transect oriented along the predominant wind direction (NNE to SSW), including the main types of particle emitters in the region. At the industrial area ( $\geq 0 \mathrm{~km}$ in Fig. 5), those pollutants had site concentrations up to $5.2(\mathrm{Ca}), 4.2$ (CHR), $4.8(\mathrm{PYR})$ and $29(\mathrm{~V})$ times higher than at the farthest north, rural location (Mixquiahuala), located $37 \mathrm{~km}$ from the industrial area (Fig. 5). At sites near or within the main north agriculture area $(-2$ to $-30 \mathrm{~km}$ in Fig. 5), most elements and PAH had intermediate concentrations.

Figure 6 illustrates four selected distribution patterns of pollutants as mapped with the median site data. Vanadium had a well-defined concentration peak $\left(>175 \mathrm{mg} \mathrm{kg}^{-1}\right)$ located $3.7 \mathrm{~km}$ to the south of the petroleum refinery and the power plant (Fig. 6a). Its concentration dropped centrifugally from there, but at faster rate toward the north than to the south, indicating air transport in this latter direction. The $\mathrm{V}$ concentration increased again southward (ca., $12 \mathrm{~km}$ from the main peak) probably due to further fossil fuel emissions from cement industries, which are also heavy users of residual petroleum and other materials (petcoke, natural gas, vehicle tires and a variety of residual materials).

Chromium had also a single concentration peak (>20 mg kg ${ }^{-1}$, Fig. 6b). In contrast with $\mathrm{V}$, this was located at the north of the valley; i.e., upwind from the industrial park. At the rest of the sampling areas, the biomonitor accumulated rather similar $\mathrm{Cr}$ levels $\left(\approx 5 \mathrm{mg} \mathrm{kg}^{-1}\right)$. Two potential sources causing that $\mathrm{Cr}$ peak are nearby polluted agriculture soils and limestone dust from quarrying.

Calcium (Fig. 6c) had two high concentration spots, one at the SE $\left(>36000 \mathrm{mg} \mathrm{kg}^{-1}\right)$ and another at the NE ( $>25000 \mathrm{mg} \mathrm{kg}^{-1}$ ) of the study region, coinciding with two major limestone areas where mining for cement materials occurs. In general, this element was more concentrated in the biomonitor at the East half of MV were limestone rocks predominate.

Figure 6d shows the distribution of total PAH. The highest concentrations were recorded at the south of MV, mainly to the WSW of the core industrial area. The lowest levels occurred at rural NW sector, upwind respect to the urban/industrial areas. The tree concentration peaks in Fig. 6d were determined by the most abundant MMW (FLT and
Table 6. Mean and standard deviation of elements $\left(\mathrm{mg} \mathrm{kg}^{-1}\right)$ and $\mathrm{PAH}\left(\mathrm{ng} \mathrm{g}^{-1}\right)$ in T. recurvata at north and south Mezquital Valley.

\begin{tabular}{lccr}
\hline Pollutant & North & South & $\mathrm{D}^{1}$ \\
\hline $\mathrm{Al}$ & $3724 \pm 919$ & $4625 \pm 2004$ & 24.2 \\
$\mathrm{Ba}$ & $31.0 \pm 6.6$ & $43.5 \pm 18.2$ & 40.3 \\
$\mathrm{Ca}$ & $9453 \pm 4074$ & $15577 \pm 7079$ & 64.8 \\
$\mathrm{Cd}$ & $2.1 \pm 0.8$ & $2.1 \pm 0.6$ & \\
$\mathrm{Cr}$ & $5.9 \pm 6.1$ & $4.7 \pm 2.2$ & \\
$\mathrm{Cu}$ & $6.1 \pm 2$ & $6.7 \pm 2.9$ & \\
$\mathrm{Fe}$ & $1283 \pm 278$ & $1848 \pm 702$ & 44.0 \\
$\mathrm{~K}$ & $7078 \pm 2058$ & $7786 \pm 1478$ & \\
$\mathrm{Li}$ & $17.0 \pm 3.2$ & $18.7 \pm 3.8$ & \\
$\mathrm{Mg}$ & $2647 \pm 693$ & $3111 \pm 971$ & 17.5 \\
$\mathrm{Mn}$ & $77.3 \pm 18.0$ & $79.4 \pm 23.7$ & \\
$\mathrm{Mo}$ & $3.2 \pm 1.7$ & $4.8 \pm 3.3$ & 50.0 \\
$\mathrm{Na}$ & $3215 \pm 1414$ & $2815 \pm 1421$ & \\
$\mathrm{Ni}$ & $11.2 \pm 5.0$ & $20.8 \pm 10.3$ & 85.7 \\
$\mathrm{P}$ & $478 \pm 131$ & $505 \pm 235$ & \\
$\mathrm{Sr}$ & $26.8 \pm 7.2$ & $34.8 \pm 14.3$ & 29.9 \\
$\mathrm{Ti}$ & $164 \pm 35$ & $230 \pm 93$ & 40.2 \\
$\mathrm{~V}$ & $21.0 \pm 7.0$ & $65.9 \pm 38.9$ & 213.8 \\
$\mathrm{Zn}$ & $31.4 \pm 6.9$ & $52.0 \pm 27.8$ & 65.6 \\
$\mathrm{NAP}$ & $55.5 \pm 39.2$ & $107 \pm 144$ & \\
$\mathrm{FLN}$ & $26.9 \pm 25.1$ & $46.9 \pm 73.3$ & \\
$\mathrm{PHE}$ & $113 \pm 55$ & $144 \pm 69$ & \\
$\mathrm{FTN}$ & $136 \pm 266$ & $159 \pm 171$ & \\
$\mathrm{PYR}$ & $16.1 \pm 8.6$ & $28.8 \pm 11.9$ & 78.9 \\
$\mathrm{CRY}$ & $14.8 \pm 7.2$ & $27.3 \pm 16.8$ & 84.5 \\
$\mathrm{BGP}$ & $25.5 \pm 12.0$ & $28.0 \pm 15.6$ & \\
\hline & & &
\end{tabular}

${ }^{1} \mathrm{D}$, significant South - North percent difference (Student $\mathrm{t}, p<0.05$ ).

PHE) and LMW (NAP) PAH, probably reflecting vehicular emissions from the closest urban settlements.

Prior to factor analysis, the element signal-to-noise ratio (SNR) and enrichment factors (EF) were considered as criteria for variable selection (see Sect. 2.3). The average SNR was 4.1 (min, 2.1, Cd; $\max , 7.3$, Ca, Table 2), a good ratio in signal information for a biomonitoring survey. Comparatively, Wolterbeek et al. (1996) reported average SNR values from 1.3 to 3.4 for lichens, mosses and tree bark biomonitors in Europe.

Figure 7 shows the mean element EFs relative to the $\mathrm{Al}$ concentrations in the regional limestone and igneous rocks. It includes only elements quantified in both rock types. Enrichment values close to 1.0 are indicative of crustal origin. Higher values, subjectively $\geq 5$, indicate enrichment by anthropogenic emissions. Since K, Ni, P, V and Zn were more enriched than expected from both rock types, they are likely to derive from industrial ( $\mathrm{Ni}, \mathrm{V}$ and $\mathrm{Zn}$ ) and, tentatively, agricultural sources ( $\mathrm{K}$ and $\mathrm{P}$ ). In contrast, $\mathrm{Na}$ was enriched only respect to limestone; whereas $\mathrm{Ca}$ and $\mathrm{Cu}$ were enriched respect to igneous rocks. The rest of elements in Fig. 7, Ba, 


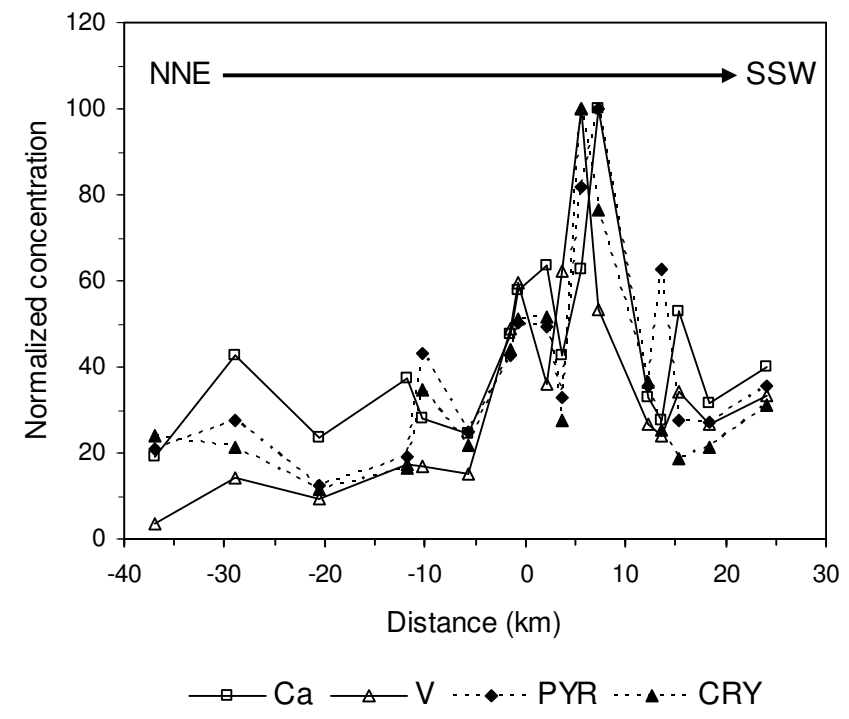

Fig. 5. Normalized median site concentration of two metals and two PAH in T. recurvata along a NNE-SSW transect at Mezquital Valley. The 100 value represents the maximum site concentration: $\mathrm{Ca}, 32600 \mathrm{mg} \mathrm{kg}^{-1}$; CRY, $82.1 \mathrm{ng} \mathrm{g}^{-1}$; PYR, 65.9 $\mathrm{ng} \mathrm{g}^{-1}$; $\mathrm{V}, 197.2 \mathrm{mg} \mathrm{kg}^{-1}$. The border between the main agricultural and industrial areas is roughly located at $\mathrm{km} 0$.

$\mathrm{Cr}, \mathrm{Mg}, \mathrm{Mn}, \mathrm{Sr}$ and Ti, probably originated from crustal/soil sources. The natural emission of some elements can be enhanced by activities like mining. This could be the case for $\mathrm{Ca}$ and $\mathrm{Cr}$, whose highest site concentrations occurred near limestone mining areas.

Table 7 shows a factor analysis solution for the $50 \mathrm{MV}$ sites $\times 20$ pollutants standardized data. Five factors (F1 to F5) or potential sources with eigenvalues $>1.0$ accounted for $74 \%$ of the data variance. Most of it (39.5\%) was associated to $\mathrm{F} 1$, which was loaded by $\mathrm{Ti}>\mathrm{Ba}>\mathrm{Fe}>\mathrm{Al}>\mathrm{Sr}>\mathrm{Cu}$ (loadings $>0.6$ ), and to some extent by $\mathrm{Ca}(0.49)$. Such composition indicates crustal sources, including both igneous rocks and limestone $(\mathrm{Ca})$. According to the site scores from FA (not shown), this factor was geographically centered at the MV agriculture/industrial frontier, $1.5 \mathrm{~km}$ from the refinery in NE direction, where the first four elements (Ti to $\mathrm{Al}$ ) peaked in concentration. This suggests soil dust traveling $\mathrm{N}$ to $\mathrm{S}$ from the agriculture areas as the element vehicle. Since most F1 elements are considerably more concentrated in the local igneous rocks than in limestone (igneous to limestone concentration ratios: $\mathrm{Al}, 106: 1 ; \mathrm{Ba}, 48: 1 ; \mathrm{Cu}$, 3:1; Fe, 1201:1; Ti 340:1, with data by Lozano and Bernal, 2005; Surendra, 2001), this factor appears more related to soil sources composed predominantly by igneous parental material.

Factor $2(11.3 \%$ of variance) was loaded $(>0.60)$ by $\mathrm{Mn}>\mathrm{Mg}>\mathrm{Zn}$, and slightly by $\mathrm{Cu}(0.44)$. Interestingly, $\mathrm{Na}$ had a negative loading $(-0.71)$ on this factor. This reflected
Table 7. Factor analysis of pollutants in T. recurvata $(\mathrm{n}=50)$.

\begin{tabular}{lrrrrr}
\hline & F1 & F2 & F3 & F4 & F5 \\
\hline $\mathrm{Ti}$ & $\mathbf{0 . 8 9}$ & 0.07 & 0.25 & 0.16 & 0.17 \\
$\mathrm{Ba}$ & $\mathbf{0 . 8 7}$ & 0.26 & 0.14 & -0.07 & 0.17 \\
$\mathrm{Fe}$ & $\mathbf{0 . 8 6}$ & 0.08 & 0.32 & 0.14 & 0.19 \\
$\mathrm{Al}$ & $\mathbf{0 . 7 8}$ & -0.30 & 0.30 & 0.08 & 0.22 \\
$\mathrm{Sr}$ & $\mathbf{0 . 7 2}$ & 0.26 & 0.25 & -0.15 & 0.21 \\
$\mathrm{Cu}$ & $\mathbf{0 . 6 1}$ & 0.44 & 0.09 & 0.27 & 0.05 \\
$\mathrm{Mn}$ & 0.25 & $\mathbf{0 . 7 0}$ & -0.14 & 0.18 & -0.18 \\
$\mathrm{Mg}$ & 0.35 & $\mathbf{0 . 6 8}$ & 0.13 & 0.24 & 0.21 \\
$\mathrm{Zn}$ & 0.24 & $\mathbf{0 . 6 6}$ & 0.57 & 0.08 & 0.19 \\
$\mathrm{Na}$ & 0.22 & $-\mathbf{0 . 7 1}$ & -0.08 & 0.37 & 0.06 \\
$\mathrm{PYR}$ & 0.17 & 0.05 & $\mathbf{0 . 8 1}$ & 0.12 & 0.03 \\
$\mathrm{~V}$ & 0.33 & 0.19 & $\mathbf{0 . 7 9}$ & -0.06 & 0.29 \\
$\mathrm{CRY}$ & 0.23 & 0.24 & $\mathbf{0 . 7 8}$ & 0.05 & 0.34 \\
$\mathrm{Ni}$ & 0.12 & -0.28 & $\mathbf{0 . 7 3}$ & -0.04 & -0.26 \\
$\mathrm{Ca}$ & 0.49 & 0.04 & $\mathbf{0 . 6 2}$ & 0.05 & 0.33 \\
$\mathrm{Bg} \mathrm{P}$ & -0.20 & 0.13 & 0.14 & $\mathbf{0 . 7 2}$ & -0.15 \\
$\mathrm{~K}$ & 0.31 & -0.02 & -0.02 & $\mathbf{0 . 7 1}$ & 0.04 \\
$\delta^{15} \mathrm{~N}$ & 0.26 & -0.19 & -0.05 & -0.2 & $\mathbf{0 . 6 9}$ \\
$\mathrm{P}$ & 0.42 & 0.27 & 0.17 & 0.08 & $\mathbf{0 . 6 7}$ \\
$\delta^{13} \mathrm{C}$ & -0.08 & -0.01 & -0.19 & -0.01 & $-\mathbf{0 . 7 3}$ \\
\% variance & 39.5 & 11.3 & 9.8 & 8.1 & 5.2 \\
\hline
\end{tabular}

a major spatial contrast between $\mathrm{Na}$, with higher concentrations ( 4000 to $5000 \mathrm{mg} \mathrm{kg}^{-1}$ ) within or near agriculture areas (Fig. 8); whereas the other elements were more concentrated at the farther rural areas to the south $\left(\mathrm{Mn}>100 \mathrm{mg} \mathrm{kg}^{-1}\right)$ and $\mathrm{SE}$ of MV $\left(\mathrm{Mg}>4000 \mathrm{mg} \mathrm{kg}^{-1}\right)$. Although $\mathrm{Zn}$ had high levels at some industrial sites $\left(>60 \mathrm{mg} \mathrm{kg}^{-1}\right)$, it kept similar concentrations at the SE rural area, resembling the Mg pattern. This factor may be also related to soil sources, but distinguishing saline agriculture soils at the MV lowlands $(\mathrm{Na})$ from natural soils $(\mathrm{Mg}, \mathrm{Mn}$ and $\mathrm{Zn})$. Sodium is the main cation in irrigation wastewater at MV (Cervantes-Medel and Armienta, 2004; Jimenez and Chávez, 2004), which is attributed transport by wastewater from the saline areas near Mexico City (Siebe, 1998). However, potential inputs from other sources for the elements loading on this factor cannot be excluded. For instance, industrial particulate matter traveling $\mathrm{N}$ to $\mathrm{S}(\mathrm{Cu}$ and $\mathrm{Zn})$ and gasoline vehicle emissions $(\mathrm{Mn})$ from a major line source located at the S limit of MV, the Mexico City-Querétaro highway.

Factor 3 (F3) accounted for $9.8 \%$ of the variance and was significantly loaded $(>0.60)$ by $\mathrm{PYR}>\mathrm{V}>\mathrm{CRY}>\mathrm{Ni}>\mathrm{Ca}$ and $\mathrm{Zn}(0.57)$. It is clearly an anthropogenic factor with pollutants from fossil fuel combustion and cement production $(\mathrm{Ca})$. The presence of $\mathrm{Ca}$ on this factor is explained by the spatial concurrence of the main petroleum combustion sources and the major limestone quarries and cement plants, which are also heavy users of fossil fuels, at the SSE sector of MV. The negative loading of $\delta^{13} \mathrm{C}$ on this factor added 


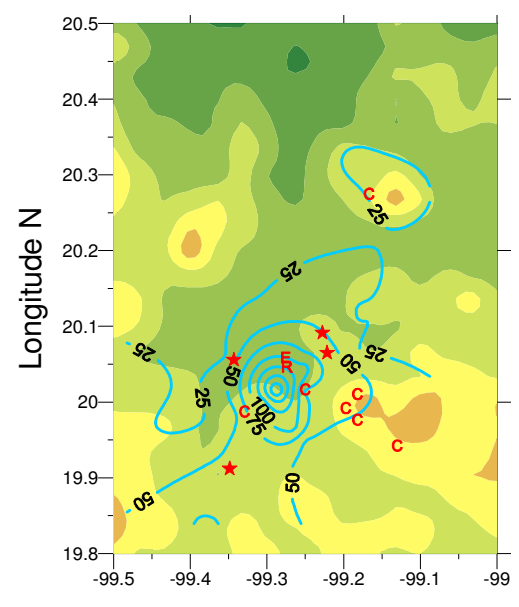

(a)

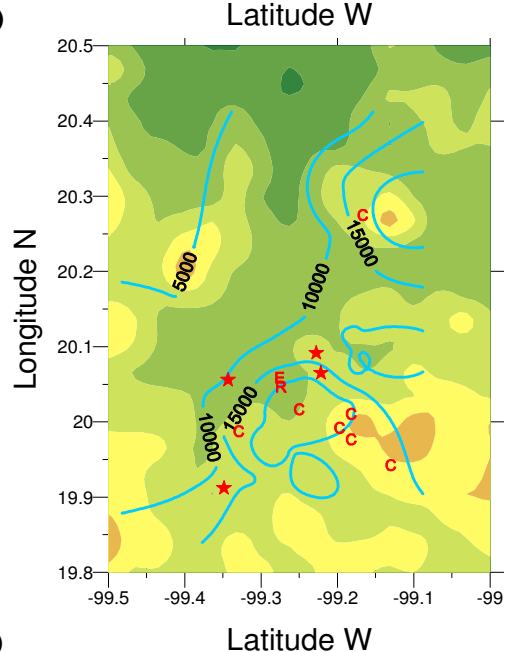

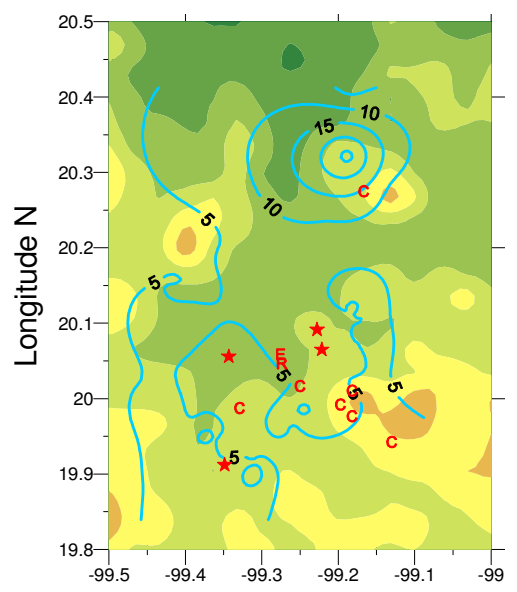

(b)

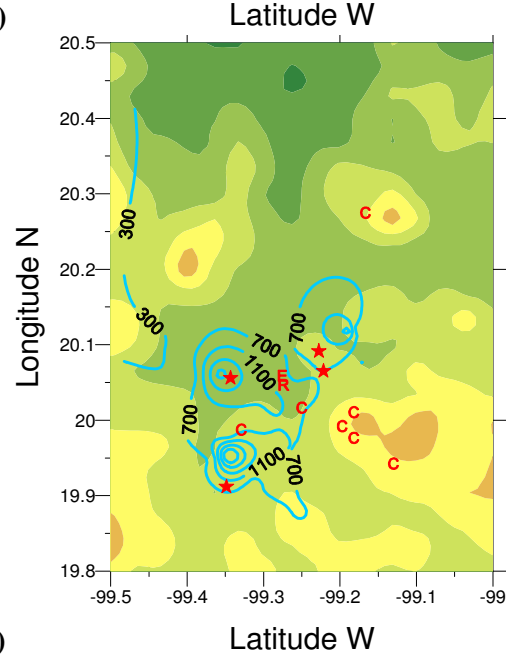

Fig. 6. Spatial distribution of $\mathrm{V}$ (a), $\mathrm{Cr}(\mathbf{b}), \mathrm{Ca}(\mathbf{c})$ and total PAH (d) in T. recurvata at Mezquital Valley. Units: $\mathrm{mg} \mathrm{kg}^{-1}$.

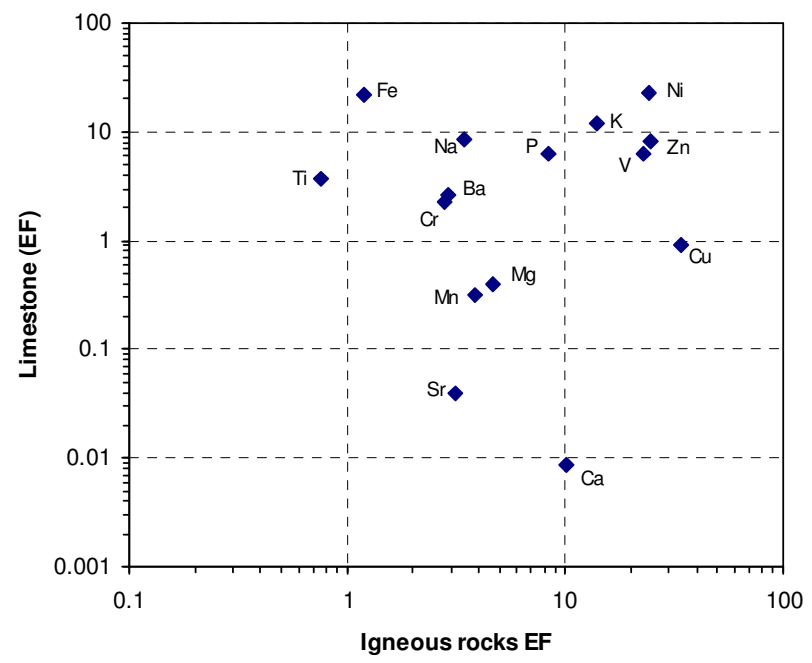

Fig. 7. Mean element enrichment factors in $T$. recurvata at Mezquital Valley.

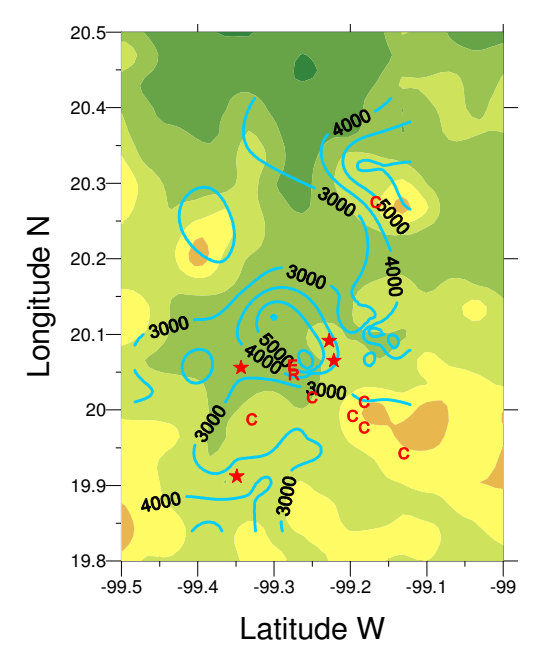

Fig. 8. Spatial distribution of $\mathrm{Na}$ in T. recurvata at Mezquital Valley. Units: $\mathrm{mg} \mathrm{kg}^{-1}$. 


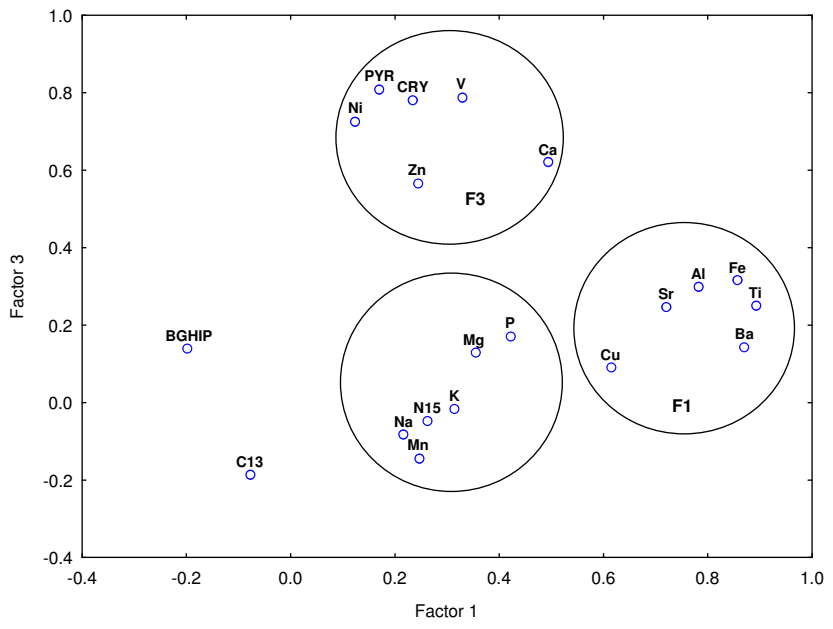

Fig. 9. Factor 3 vs. factor 1 plot. F1 includes elements from mainly crustal origin; F3, elements and PAH from petroleum fuel combustion and cement production $(\mathrm{Ca})$. The third circle includes elements related to agriculture soil sources (F2, F4 and F5, not shown).

further evidence to associate it with petroleum combustion. Figure 9 illustrates how these pollutants separate in the factor space from the predominantly crustal/soil elements (Al, Ba, $\mathrm{Cu}, \mathrm{Fe}, \mathrm{Sr}$ and $\mathrm{Ti})$.

Factor $4(\mathrm{~F} 4)$ had $8.1 \%$ of the variance associated with it. It was loaded by $\mathrm{K}$ and benzo $(g, h, i)$ perylene, deriving tentatively from biomass burning, which may include agriculture debris in the flatlands and forest fires in the highlands at the $\mathrm{W}$ side of MV.

Factor 5 (F5) accounted only by $5.2 \%$ of the variance. It was loaded by the $\delta^{15} \mathrm{~N}$ isotope ratio and P. This factor may reflect agriculture activities with wastewater, characterized by large emissions of $\mathrm{N}$ compounds, mainly $\mathrm{NH}_{3}, \mathrm{NH}_{4}^{+}$and $\mathrm{NO}_{3}^{-}$(Cervantes-Medel and Armienta, 2004; Jimenez and Chávez, 2004) and P (Ortega-Larrocea et al., 2001). Phosphorus may also derive from pesticides used in agriculture, which often contain this element. The negative loading of $\delta^{13} \mathrm{C}$ on this factor added evidence on the regional difference between agriculture and industrial (fossil fuel combustion) land uses.

Although FA did not extracted pure factors/sources, it acceptably distinguished contributions from the most relevant sources of particulate matter into the MV air. Most element variability in the biomonitor, $64 \%$ out of $74 \%$ total explained variance, appeared associated with crustal/soil sources and agriculture activities $(\mathrm{F} 1+\mathrm{F} 2+\mathrm{F} 4+\mathrm{F} 5)$, and only $10 \%$ (F3) was attributable to emissions from industrial fossil fuel combustion, including power generation, petroleum refining and cement production. Increasing the number of sampling sites, especially around some major fixed sources, such as the power plant and cement factories, may allows us to differentiate their particular contributions to the load of bioaccumulative atmospheric pollutants in the study region.

\section{Conclusions}

This survey produced previously unknown information on the regional levels, sources and dispersion of airborne metals and PAH for Mezquital Valley, Mexico. Tillandsia recurvata was confirmed as a good natural receptor for those pollutants. The site to site concentration variability, as indicated by high signal-to-noise ratios for most metals $(>3.0)$, reflected the differential long-term exposition to most measured pollutants, especially to the anthropogenic ones. Some anthropogenic metals (e.g., $\mathrm{Ni}, \mathrm{Pb}$ and $\mathrm{V}$ ) had particularly high concentrations respect to values for similar biomonitors in other countries, indicating that atmospheric deposition should be several times higher at this Mexican region. The levels of PAH were more similar to values for Tillandsia biomonitors, with a few exceptions (e.g., ACY and I $c d \mathrm{P}$ ). The southern industrial portion of MV was more polluted than the agricultural north, as implied by the higher concentrations of 11 elements and two PAH. From the chemical correlation between the biomonitor and the regional rocks, results from factor analysis and the geographic patterns of pollutants, it is concluded that crustal/soil sources had a higher relative impact than agriculture and industry on the spatial variability of pollutants. The high "background" $\delta^{13} \mathrm{C}$ and low $\delta^{15} \mathrm{~N}$ of T. recurvata make this epiphyte a sensitive biomonitor for ${ }^{13} \mathrm{C}$-depleted and ${ }^{15} \mathrm{~N}$-enriched sources. It may be thus recommendable to use it as a common natural receptor for comparative studies within and among Latin American countries and the southern US states, where it is naturally distributed. This would minimize potential variability from using different species.

Acknowledgements. This study was funded by the Mexican Oil Company (PEMEX, project F.21393) and the Mexican Petroleum Institute (D.00391), and conducted under the MILAGRO 2006 Mexico field campaign. We thank Marina Morán Pineda, executive of the IMP Gas Spectroscopy and Environmental Studies Laboratory, for logistical support; Ingrid García Torres and José Rojas for assistance in the sample preparation process; Adolfo Espejo Serna and Ana Rosa López Ferrari, with the Metropolitan University Herbarium at Mexico City, for taxonomical identification of our samples. We also express our gratitude to three anonymous reviewers, who greatly helped us to improve this work.

Edited by: L. Molina

\section{References}

Aboal, J. R., Real, C., Fernández, J. A., and Carballeira, A.: Mapping the results of extensive surveys: the case of atmospheric biomonitoring and terrestrial mosses, Sci. Total Environ., 356, 256-274, 2006.

Bairwise, A. J. G.: Role of nickel and vanadium in petroleum classification, Energ. Fuel., 4, 647-652, 1990. 
Benzig, D. H., Arditti, J., Nyman, L. P., Temple, P. J., and Adams, J. P.: Effects of ozone and sulfur dioxide on four bromeliads, Environ. Exp. Bot., 32(1), 25-29, 1992.

Boutton, T. W.: Stable carbon isotope ratios of natural materials: II, Atmospheric, terrestrial, marine and freshwater environments, in: Carbon Isotope Techniques, edited by: Coleman, D. C. and Fry, B., 173-185, 1991.

Branquinho, C., Gaio-Oliveira, G., Augusto, S., Pinho, P., Máguas, C., and Correia, O.: Biomonitoring spatial and temporal impact of atmospheric dust from a cement industry, Environ. Pollut., 151(2), 292-299, 2008.

Brenninkmeijer, C. A. M., Janssen, C., Kaiser, J., Röckmann, T., Rhee, T. S., and Assonov, S. S.: Isotope effects in the chemistry of atmospheric trace compounds, Chem. Rev., 103, 5125-5161, 2003.

Brighina, L., Papini, A., Mosti, S., Cornia, A., Bocchini, P., and Galleti, G.: The use of tropical bromeliads (Tillandsia spp.) for monitoring atmospheric pollution in the town of Florence, Italy, Rev. Biol. Trop., 50(2), 577-584, 2002.

Bukata, A. R. and Kyser, T. K.: Carbon and nitrogen isotope variations in tree-rings as records of perturbations in regional carbon and nitrogen cycles, Environ. Sci. Technol., 41, 1331-1338, 2007.

Cabrera Ruíz, R. B. E., Gordillo Martínez, A. J., and Cerón Beltrán, A.: Inventario de contaminación emitida a suelo, agua y aire en 14 municipios del Estado de Hidalgo, México, Rev. Int. Contam. Ambie., 19(4), 171-171, 2003.

Castro, L. V. and Vazquez, F.: Fractionation and characterization of Mexican crude oils, Energ. Fuel., 23(3), 1603-1609, 2009.

CEPAL-SEMARNAT: Evaluación de las externalidades ambientales de la generación termoeléctrica en México, http://www. semarnat.gob.mx/informacionambiental/Publicacion/ext.pdf, 2004.

Cervantes-Medel, A. and Armienta, M. A.: Influence of faulting on groundwater quality in Valle del Mezquital, Mexico, Geofísica Internacional, 43(3), 477-493, 2004.

Cifuentes, E., Blumenthal, U., Ruíz Palacios, G., Bennett, S., and Peasey, A.: Epidemiological panorama for the agricultural use of wastewater: The Mezquital Valley, Mexico, Salud Pública México, 36, 3-9, 1994.

Cole, M. L., Valiela, I., Kroeger, K. D., Tomansky, G. L., Cebrian, J., Wigand, C., McKinney, R. A., Grady, S. P., and Carvalho da Silva, M. H.: Assessment of a $\delta^{15} \mathrm{~N}$ isotopic method to indicate anthropogenic eutrophication in aquatic ecosystems, J. Environ. Qual., 33, 124-132, 2004.

Conti, M. E. and Cecchetti, G.: Biological monitoring: lichens as bioindicators of air pollution assessment - a review, Environ. Pollut., 114, 471-492, 2001.

Coplen, T. B.: Discontinuance of SMOW and PDB, Nature, 375, 285 pp., 1995.

Crayn, D. M., Winter, K., and Smith, J. A. C.: Multiple origins of crassulacean acid metabolism and the epiphytic habit in the Neotropical family Bromeliacea, PNAS, 101(10), 3703-3708, 2004.

De Sousa Pereira, M., Heitmann, D., Reifenhäuser, W., Ornellas Meire, R., Silva Santos, L., Torres, J. P. M., Malm, O., and Körner, W.: Persistent organic pollutants in atmospheric deposition and biomonitoring with Tillandsia usneoides (L.) in an industrialized area in Rio de Janeiro state, southeast Brazil - Part
II: PCB and PAH, Chemosphere, 67, 1736-1745, 2007.

Downs, T. J., Cifuentes-García, E., and Buffet, I. M.: Risk screening for exposure to groundwater pollution in a wastewater irrigation district of the Mexico City region, Environ. Health Persp., 107(7), 553-561, 1999.

EPA: Method 6010C. Inductively Coupled Plasma-Atomic Emission Spectrometry, Revision 3, 30 pp., 2000.

Espinosa Pena, M., Manjarrez, A., and Campero, A.: Distribution of vanadyl porphyrins in a Mexican offshore heavy crude oil, Fuel Process. Technol., 46, 171-182, 1996.

Figuereido, A. M., Nogueira, C. A., Saiki, M., Milian, F. M., and Domingos, N.: Assessment of atmospheric metallic pollution in the metropolitan region of São Paulo, Brazil, employing Tillandsia usneoides L. as biomonitor, Environ. Pollut., 145(1), 279292, 2007.

Friedel, J. K., Langer, T., Siebe, C, and Stahr, K.: Effects of longterm waste water irrigation on soil organic matter, soil microbial biomass and its activities in central Mexico, Biol. Fert. Soils, 31(5), 441-421, 2000.

Flores-Delgadillo, L., Hernández-Silva, G., Alcalá-Martínez, R., and Maples-Vermeersch, M.: Total contents of cadmium, copper, manganese and zinc in agricultural soils irrigated with wastewater from Hidalgo, Mexico, Rev. Int. Contam. Ambie., 8(1), 3746, 1992.

Ganor, E., Altshuller, S., Foner, H. A., Brenner, S., and Gabay, J.: Vanadium and nickel in dustfall as indicators of power plant pollution, Water Air Soil Pollut., 42, 241-252, 1988.

Gerdol, R., Bragazza, L., Marchesini, R., Medici, A., Pedrini, P., Benedetti, S., Bovolenta, A., and Coppi, S.: Use of moss (Tortula muralis Hedw.) for monitoring organic and inorganic air pollution in urban and rural sites in Northern Italy, Atmos. Environ., 36, 4069-4075, 2002.

González-Méndez, B., Siebe, C., Fiedel, S., Hernández, J. M., and Ruíz-Suárez, L. G.: $\mathrm{N}_{2} \mathrm{O}$ emissions from soil irrigated with untreated wastewater in central Mexico, J. Soil Sci. Plant Nutr., 8(3), 185, 2008.

Hernández-Silva, G., Flores-Delgadillo, L., Maples-Vermeersch, M., Solorio-Munguía, J. G., and Alcalá-Martínez, J. R.: Riesgo de acumulación de $\mathrm{Cd}, \mathrm{Pb}, \mathrm{Cr}$ y Co en tres series de suelos del DR03, Estado de Hidalgo, México, Revista Mexicana de Ciencias Geológicas, II(1), 53-61, 1994.

Hietz, P. and Wanek, W.: Size-dependent variation of carbon and nitrogen isotope abundances in epiphytic bromeliads, Plant Biol., 5, 137-142, 2003.

Hietz, P., Wanek, W., and Popp, M.: Stable isotopic composition of carbon and nitrogen and nitrogen content in vascular epiphytes along an altitudinal transect, Plant Cell Environ., 22, 1435-1443, 1999.

Huerta, L., Contreras-Valadez, R., Palacios-Mayorga, S., Miranda, J., and Calva-Vasquez, G.: Total element composition of soils contaminated with wastewater irrigation by combining IBA techniques, Nucl. Instrum. Meth. B, 189, 158-162, 2002.

Husk, G. J., Weishampel, J. F., and Schlesinger.: Mineral dynamics in Spanish moss, Tillandsia usneoides L. (Bromeliacea), from Central Florida, USA, Sci. Total Environ., 321, 165-172, 2004.

Hwang, H. M., Wade, T. L., and Sericano, J. L.: Concentrations and source characterization of polycyclic aromatic hydrocarbons in pine needles from Korea, Mexico, and United States, Atmos. Environ., 37, 2259-2267, 2003. 
Jimenez, B. and Chávez, A.: Quality assessment of an aquifer recharged with wastewater for its potential use as drinking source: "El Mezquital Valley" case, Water Sci. Technol., 50(2), 269-276, 2004.

Jung, K., Gebauer, G., Gehre, M., Hoffmann, D., Weißflog, L., and Schüürmann, G.: Anthropogenic impacts on natural nitrogen isotope variations in Pinus sylvestris stands in an industrially polluted area, Environ. Pollut., 97(1-2), 175-181, 1997.

Kelly, S. D., Stein, C., and Jickells, T. D.: Carbon and nitrogen isotopic analysis of atmospheric organic matter, Atmos. Environ., 39, 6007-6011, 2005.

Krupa, S.: Effects of atmospheric ammonia $\left(\mathrm{NH}_{3}\right)$ on terrestrial vegetation: a review, Environ. Pollut., 124, 179-221, 2003.

Liu, X. Y., Xiao, H. Y., Liu, C. Q., Li, Y. Y., and Xiao, H. W.: Stable carbon and nitrogen isotopes of the moss Haplocladium microphyllum in an urban and a background area (SW China): the role of environmental conditions and atmospheric nitrogen deposition, Atmos. Environ., 42, 5413-5423, 2008.

Lozano, R. and Bernal, J. P.: Characterization of a new set of eight geochemical reference materials for XRF major and trace element analysis, Revista Mexicana de Ciencias Geológicas, 22(3), 329-344, 2005.

Lucho-Constantino, C. A., Álvarez-Suárez, M., Beltrán-Hernández, R. I., Prieto-García, F., and Poggi-Varaldo, H. M.: A multivariate analysis of the accumulation and fractionation of major and trace elements in agricultural soils in Hidalgo State, Mexico irrigated with raw wastewater, Environ. Int., 31(3), 313-323, 2005.

Macko, S. A. and Parker, P. L.: Stable nitrogen and carbon isotope ratios of beach tars on South Texas Barrier Islands, Mar. Environm. Res., 10, 93-103, 1983.

Malm, O., de Freitas Fonseca, M., Hissnauer Miguel, P., Rodríguez Bastos, W., and Neves Pinto, F.: Use of epiphyte plants as biomonitors to map atmospheric mercury in a gold trade center city. Amazon, Brazil, Sci. Total Environ., 213(1-3), 57-64, 1998.

Mariotti, A.: Natural N-15 abundance measurements and atmospheric nitrogen Standard calibration, Nature, 311, 685-687, 1974.

Martin, C. E.: Physiological ecology of the Bromeliaceae, Bot. Rev., 60(1), 1-82, 1994.

Norra, S., Handley, L. L., Berner, Z., and Stüben, D.: ${ }^{13} \mathrm{C}$ and ${ }^{15} \mathrm{~N}$ natural abundances of urban soils and herbaceous vegetation in Karlsruhe, Germany, Eur. J. Soil Sci., 56(5), 607-620, 2005.

Ortega-Larrocea, M. P., Siebe, C., Bécard, G., Méndez, I., and Webster, R.: Impact of a century of wastewater irrigation on the abundance of arbuscular mycorrhizal spores in the soil of the Mezquital Valley of Mexico, Appl. Soil Ecol., 16(2), 149-157, 2001.

Pardo, L. H., McNulty, S. G., Bogs, J. L., and Duke, S.: Regional patterns in foliar ${ }^{15} \mathrm{~N}$ across a gradient of nitrogen deposition in the northeastern US, Environ. Pollut., 149, 293-302, 2007.

Pearson, J., Wells, D. M., Seller, K. J., Bennett, A., Soares, A., Woodall, J., and Ingrouille, M. J.: Traffic exposure increases natural ${ }^{15} \mathrm{~N}$ and heavy metal concentrations in mosses, New Phytol., 147(2), 317-326, 2002.

Pichlmayer, F., Schöner, W., Seibert, P., Stichler, W., and Wagenbach, D.: Stable isotope analysis for characterization of pollutants at high elevation alpine sites, Atmos. Environ., 32(23), 4075-4085, 1998.
Pierce, S., Winter, K., and Griffiths, H.: Carbon isotope ratio and the extent of daily CAM use by Bromeliaceae, New Phytol., 156, 75-83, 2002.

Pignata, M. L., Gudiño, G. L., Wannaz, E. D., Plá, R. R., González, C. M., Carreras, H. A., and Orellana, L.: Atmospheric quality and distribution of heavy metals in Argentina employing Tillandsia capillaris as a biomonitor, Environ. Pollut., 129, 59-68, 2002.

Pirintsos, S. A. and Loppi, S.: Biomonitoring atmospheric pollution: the challenge of times in environmental policy on air quality, Environ. Pollut. 151(2), 269-271, 2008.

Prinzhofer, A., Vega, M. A. G., Battani, A., and Escudero, M.: Gas geochemistry of the Macuspana Basin (Mexico): thermogenic accumulations in sediments impregnated by bacterial gas, Mar. Petrol. Geol., 17, 1029-1040, 2000.

Puente, M. E. and Bashan, Y.: The desert epiphyte Tillandsia recurvata harbours the nitrogen-fixing bacterium Pseudomonas stutzeri, Can. J. Bot., 72, 406-408, 1994.

Pyatt, F. B., Grattan, J. P., Lacy, D., Pyatt, A. J., and Seward, M. R. D.: Comparative effectiveness of Tillandsia usneoides L. and Parmotrema praesorediosum (Nyl.) Hale as bio-indicators of atmospheric pollution in Louisiana (U.S.A.), Wate Air Soil Poll., 111, 317-326, 1999.

Rossini Oliva, S. and Raitio, H.: Review of cleaning techniques and their effects on the chemical composition of foliar samples, Boreal Environ. Res., 8, 263-272, 2003.

Schmitt, A. K., Martin, C. E., and Lüttge, U. E.: Gas exchange and water vapor uptake in the atmospheric bromeliad Tillandsia recurvata L, Bot. Acta, 102, 80-84, 1989.

Schrimpff, E.: Air pollution patters in two cities of Colombia according to trace substances contents of an epiphyte Tillandsia recurvata, Water Air Soil Poll., 21(1-4), 279-316, 1984.

Segala, E. A., Baêsso, B. M., and Domingos, M.: Structural analysis of Tillandsia usneoides L. exposed to air pollutants in São Paulo city-Brazil, Water Air Soil Poll., 189, 61-68, 2008.

SEMARNAT-INE.: Inventario Nacional de Emisiones de México, 1999, Secretaría del Medio Ambiente y Recursos Naturales/Instituto Nacional de Ecología, México, D. F., 409 pp., 2006.

Siebe, C.: Acumulación y disponibilidad de metales pesados en suelos regados con aguas residuales en el distrito de riego 03, Tula, Hidalgo, México, Revista Internacional de Contaminación Ambiental, 10(1), 15-21, 1994.

Siebe, C.: Nutrient inputs to soils and their uptake by alfalfa through long-term irrigation with untreated sewage effluent in Mexico, Soil Use Manage., 14, 119-122, 1998.

Siebe, C., and Cifuentes, E.: Environmental impact of wastewater irrigation in central Mexico: an overview, Int. J. Environ. Heal. R., 5, 161-173, 1995.

Silva-Mora, L.: Geología volcánica y carácter químico preliminar de las rocas de la regón Tula-Polotitlán, Estados de Hidalgo, México y Querétaro, México, Revista Mexicana de Ciencias Geológicas, 14(1), 50-77, 1997.

Skinner, R. A., Ineson, P., Jones, H., Sleep, D., Leith, I. D., and Sheppard, L. J.: Heathland vegetation as a bio-monitor for nitrogen deposition and source attribution using $\delta^{15} \mathrm{~N}$ values, Atmos. Environ., 40, 498-507, 2006.

Sloof, J. E.: Lichens as quantitative biomonitors for atmospheric trace element deposition, using transplants, Atmos. Environ., 
29(1), 11-20, 1995.

SMA.: Gestión Ambiental del Aire en el Distrito Federal: Avances y Propuestas, 2000-2006, Secretaría del Medio Ambiente, Gobierno del Distrito Federal, México, 2006.

Smodiš, B., Pignata, M. L., Saiki, M., Cortés, E., Bangfa, N., Markert, B., Nyarko, B., Arunachalam, J., Garty, J., Vutchkov, N., Wolterbeek, H. Th., Steinnes, E., Freitas, M. C., Lucaciu, A., and Frontasyeva, M.: Validation and application of plants as biomonitors of trace atmospheric pollution- a co-ordinated effort in 14 countries, J. Atmos. Chem., 49, 3-13, 2004.

Solga, A., Burkhardt, J., Zechmeister, H. G., and Frahm, J. P.: Nitrogen content, ${ }^{15} \mathrm{~N}$ abundance and biomass of the two pleurocarpous mosses Pleurozium schreberi (Brid.) Mitt. and Scleropodium purum (Hedw.) Limpr. in relation to atmospheric nitrogen deposition, Environ. Pollut., 134, 465-473, 2005.

Solga, A., Eichert, T., and Frahm, J. P.: Historical alteration in the nitrogen concentration and ${ }^{15} \mathrm{~N}$ natural abundance of mosses in Germany: indication for regionally varying changes in atmospheric nitrogen deposition within the last 140 years, Atmos. Environ., 40, 8044-8055, 2006.

St. Clair, S. B., St. Clair, L. L., Mangelson, N. F., and Weber, D. J.: Influence of growth form on the accumulation of airborne copper by lichens, Atmos. Environ., 36, 5637-5644, 2002.

Surendra, P. V.: Geochemical and Sr-Nd-Pb isotopic evidence for a combined assimilation and fraccional crystallisation process for volcanic rocks from the Huichapan caldera, Hidalgo, Mexico, Lithos, 56(2-3), 141-164, 2001.
Vázquez-Alarcón, A., Justin-Cajuste, L., Siebe-Grabach, C., Alcántar-González, G., and de la Isla de Bauer, M. L.: Cadmio, niquel y plomo en agua residual, suelo y cultivos en el Valle del Mezquital, Hidalgo, México, Agrociencia, 35, 267-274, 2001.

Wannaz, E. D. and Pignata, M. L.: Calibration of four species of Tillandsia as biomonitors, J. Atmos. Chem., 53(3), 185-209, 2006a.

Wannaz, D. E., Carreras, H. A., Pérez, C. A., and Pignata, M. L.: Assessment of metal accumulation in two species of Tillandsia in relation to atmospheric sources in Argentina, Sci. Total Environ., 361, 267-278, 2006b.

Wigand, C., McKinney, R. A., Cole, M. L., Thursby, G. B., and Cummings, J.: Varying stable nitrogen isotope ratios of different coastal marsh plants and their relationships with wastewater nitrogen and land use in New England, USA, Environ. Monit. Assess., 131, 71-81, 2007.

Wolterbeek, H. Th.: Biomonitoring of trace element air pollution: principles, possibilities and perspectives, Environ. Pollut., 120, 11-21, 2002.

Wolterbeek, H. Th., Bode, P., and Verburg, T. G.: Assessing the quality of biomonitoring via signal-to-noise ratio analysis, Sci. Total Environ., 180, 107-116, 1996. 